\title{
Tracking and Monitoring Leaf Development, Coupling Law and Regulation Techniques during Flowering Period of Hybrid Foxtail Millet (Setaria italica (L.) P. Beauv.) Parental Lines
}

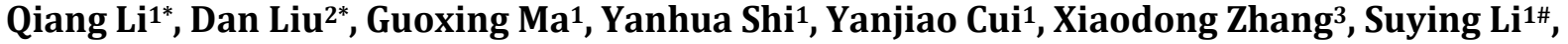 \\ Zhengli Liu1\# \\ ${ }^{1}$ Department of Life Sciences, Tangshan Normal University, Tangshan, China \\ ${ }^{2}$ Tianjin Key Laboratory of Crop Genetics and Breeding, Tianjin Crop Research Institute, Tianjin Academy of Agricultural \\ Sciences, Tianjin, China \\ ${ }^{3}$ Institute of Coastal Agriculture, Hebei Academy of Agricultural and Forestry Sciences, Tangshan, China \\ Email: \#liuzhengli65@126.com, \#lisuying65@126.com
}

How to cite this paper: Li, Q., Liu, D., Ma, G.X., Shi, Y.H., Cui, Y.J., Zhang, X.D., Li, S.Y. and Liu, Z.L. (2021) Tracking and Monitoring Leaf Development, Coupling Law and Regulation Techniques during Flowering Period of Hybrid Foxtail Millet (Setaria italica (L.) P. Beauv.) Parental Lines. Agricultural Sciences, 12, 84-111. https://doi.org/10.4236/as.2021.122007

Received: January 11, 2021

Accepted: February 21, 2021

Published: February 24, 2021

Copyright $\odot 2021$ by author(s) and Scientific Research Publishing Inc. This work is licensed under the Creative Commons Attribution International License (CC BY 4.0).

http://creativecommons.org/licenses/by/4.0/

(c) (i) Open Access

\begin{abstract}
The determining factor of Setaria italica (L.) P. Beauv. is the coupling of its flowering stage and outcrossing rate which leads to low and unstable seed yields in self-pollinated foxtail millet hybrids and thereby limits their large-scale application. In this study, Datong 27, Datong 29 and gu 83 were screened and identified through meticulous observations of their pollination habitats. High exposure rate, degree of exposure and plump of stigma are good factors to accept foreign pollen. Datong 27 and Datong 29 have some additional characteristics, such as long filaments and exposed and full anthers that contain a large amount of pollen. We transformed into a series of stigma-exposed and plump sterile lines that easily accepted exotic pollen. New restorer lines with anthers that were full of powder and exhibited quick recovery, which improved the parental lines' heterosexual characteristics. By tracking and monitoring the leaf development of the new sterile and restorer lines, a coupling law of leaf development was determined and a series of flowering control measures were formulated. These factors ensured that the parental lines encounter one another during the flowering stage. By utilizing fertilizer and water, the vitality of the female stigma, amount of powder scattered and powder loosening time were prolonged, which increased hybrid
\end{abstract}

${ }^{\star}$ Contributed equally to this work and are co-first authors. 
seed yields from 1500 to $3000 \mathrm{~kg} / \mathrm{hm}^{2}$. These findings were helpful in resolving the technical problems of seed production that restricted the propagation of foxtail millet hybrids and supporting future large-scale applications.

\section{Keywords}

Foxtail Millet, Hybrids, Leaf Age Coupling Law, Flowering Regulation, Seed Production Technology

\section{Introduction}

In recent years, the utilization of foxtail millet heterosis has progressed in China. The yield per unit of foxtail millet hybrids producing over $11,250 \mathrm{~kg} / \mathrm{hm}^{2}$ [1] [2]. As a self-pollinating crop, foxtail millet has a small amount of pollen, short propagation distance, low outcrossing rate, and sensitive photo-temperature response. During the seeding process, changes in the environment can lead to florescence in hybrid parents that do not meet [3]. As a result, florescences that do not meet and low outcrossing rates lead to low hybrid seed yields and instability, thereby limiting the large-scale application of foxtail millet hybrids.

Because foxtail millet is mainly distributed developing countries, such as China and India, research on foxtail millet lags behind that of other cereal crops. Coupled with self-pollination, foxtail millet heterosis has been difficult to study. Research on foxtail millet in Japan and the United States has mainly focused on its conservation, utilization of resources and gene mining [4]. In France and Canada, breeding of herbicide-resistant varieties has been conducted [5] [6] [7]. In Australia, foxtail millet varieties have been developed for foraging grass [8]. Meanwhile, India and similar countries still rely on conventional breeding of foxtail millet [9]. Currently, there were no reports on the use of millet heterosis.

China is the only country in the world that systematically studies the utilization of millet heterosis [3]. Since 1980s, the researchers have attempted to increase the seed yields of foxtail millet hybrids by various methods, such as the selection and application of photo-thermophilic male sterile lines [10]. In the cold-growing hilly area of a seed production site [11]. Using the cultivation method, the ratio of female and male were reduced and the planting line spacing of the sterile lines was shortened, in order to decrease the distance between sterile and restorer lines [12], and ensured that the parental lines encounter one another during the flowering stage by sowing within a certain time interval [13]. However, these effects on seed production were limited. Due to foxtail millet's sensitivity to light and temperature, the flowering stage will not be synchronized and production is thereby reduced. Currently, a high-crossing rate of a sterile or restorer line has not been achieved and the development of leaf age in sterile and restorer lines has not been identified, and a series of control measures have not 
been formulated to ensure that the parental lines encounter one another during the flowering stage to improve seed yields.

In other crops, research on high-yield and highly-efficiently seed production techniques has been reported. For example, in cross-pollinating crops and regular pollen crops, such as maize and sorghum, the flowers possess a large amount of pollen and the transmission distance is long. Based on the heading period of the male and female parental lines, when sowing is conducted within a certain time interval, the parental lines encounter one another during the flowering stage. When the male parental line has more tassel branches and full anthers, pollination is improved [14] [15] and seed yields are increased. Moreover, these crops are not sensitive to light and temperature.

Rice and foxtail millet are self-pollinating crops, and the promotion speed of rice hybrids is limited by seed yields. For this reason, rice researchers have conducted some studies on the exposure rates and degrees of rice stigma. For example, some researchers believed that rice stigma exposure rate was a quality trait controlled by major genes [16]. Some studies had suggested that the stigma exposure rate was a quantitative trait controlled by multiple genes, but the dominant effect was larger [17] [18]. Other researchers suggested that this trait was controlled by multiple genes and that the broad heritability was as high as $90 \%$ 96.86\% [19] [20]. However, these studies had mainly focused on the inheritance of the stigma exposure rate and related gene mining. A few reports were available on the creation of rice sterile lines with high stigma exposure rates and no restorer lines with high outcrossing rates. Moreover, the thousand-grain weight of rice was generally $18-34 \mathrm{~g}$ [21], and the flowers were relatively large, while the foxtail millet weight is only $2.2-3.3 \mathrm{~g}$, and the flowers were small, $\sim 1 / 9$ that of rice [22]. Most of the results of rice do not apply in foxtail millet.

The relationship between leaf age development and ear differentiation had been investigated in different crops [23]. In recent years, the influence of the relationship between leaf and ear development by nutrients has been studied [24]. However, such studies rarely used seed production technology, and no studies have reported on the coupling law of parental leaf age development based on the encounter of hybrid parental lines.

In terms of flowering regulation, some studies on different seedling sizes and hormone regulation have been conducted in hybrid parental lines [25] [26], but were lacking in regulatory measures of specific flowering types.

Based on foxtail millet's sensitivity to light and temperature, self-pollination, and low-crossing rate, this study investigated the floral characteristics of foxtail millet, identifying and screening some resources with floral openings at a high level, high stigma exertion rates, high degrees of exertion, plump stigma fullness, long filaments and exposed anthers. Additionally, through crossing, backcrossing and other methods, these characteristics were separately introduced in sterile and restoring lines. Sterile lines with strong pollination and restorative lines with strong loose powder abilities were created to improve outcrossing rates. By 
tracking and monitoring the developmental dynamics of foxtail millet hybrid parental leaves, it was possible to detect and promote coupling during the flowering stage of hybrid parental lines, as well as determine key leaf age nodes that regulate the parental lines based on the relationship between leaf and ear differentiation. Moreover, by studying agronomic regulation, fertilizer and water regulation, physiological and chemical control measures, a coupling law of leaf development for the parental lines was formulated, and a series of targeted control measures were developed to ensure foxtail millet hybrid parental line encounters in the flowering stage, enhanced outcrossing rates and seed yields. Thus, the findings of this study resolve the problem of restricted extension of foxtail millet hybrids that had low and unstable seed yields.

\section{Materials and Methods}

\subsection{Identification and Screening of Foxtail Millet Parental Lines}

The experiment was carried out in Shijiazhuang, China, from 2007 to 2008. Three thousand varieties of foxtail millet were collected from various ecological areas throughout China. Randomly planted in identification nursery of germplasm resource, and used to identify foxtail millet resources.

At the flowering stage, a magnifying glass was used for preliminary observation and screening. Three plants (three replication) with high stigma exertion rates were screened, and the ears were transferred to the laboratory for observation under stereo microscope (SZ61, Olympus, Tokyo, Japan), one grain was selected from the middle, upper and middle-lower parts of the ear every plant. The stigma exertion rate, exposure degree, and pinnate stigma development were further observed from 6:30 to 7:30 am every day. During the observation of the stigma exposure rate, the flowering number and stigma exposure were counted every day, and the flowering florets were removed. The remaining florets on the grain were placed in a beaker of water and observed after the next day of flowering. Flowering takes $3-4$ days and one spikelet was observed. Through the above observations, foxtail millet resources with obvious stigma exertion, high exertion rates and plump stigma were screened, photographed, and labeled as R11, R12, R13 and so on.

Moreover, a magnifying glass was used to screen the anthers from the selected test materials, and the anthers of these test materials were completely exposed. Then, the ears were transferred to the laboratory for observation under a stereo microscope. Materials with full anthers and loose powder were selected, photographed separately, and labeled as R21, R22, R23 and so on.

\subsection{Emergence of Foxtail Millet Sterile Lines with High Outcrossing Rates}

The sterile line, 1066A, was used as the female parental line to prepare a series of hybrids with male parental lines selected from the foxtail millet breeding materials, R11, R12, R13, etc., that exhibited obvious stigma exertion, high exertion 
rates, and plump stigma.

The first generation of hybrids (a series of hybrid combinations) was prepared from the aforementioned parental lines, and sowing was conducted in a selective nursery. After maturity, 3 - 4 plants with good seed and full individuals were selected, harvested and threshed for seeding in the next year.

Single plants harvested from the previous generation were interlaced and planted separately with the male parental lines, R11, R12, R13, etc. The stigma developmental characteristics of isolated sterile plants were observed using a magnifying glass. Single plants with high exogenous rates were selected. These infertile plants were backcrossed with the male parent. After maturity, sterile plants were mixed and harvested. The backcrossed first-generation seeds were subsequently obtained and labeled as B11, B12, B13 and so on.

After continuous observation of the stigma traits of the sterile offspring plants and continuous directional selection, multiple stable sterile ear rows with the target traits were obtained. Then, after two consecutive years, observation of the stigma traits met the target trait requirements; the ear row was a sterile line created with obvious stigma exposed, a high exposure rate and plump stigma.

\subsection{Creation of Foxtail Millet Restoration Lines with Powder-Removing Ability}

First, the female materials, R21, R22, R23, etc., which had full anthers and loose powder contents, were crossed with the male materials K359 and K492 with herbicide-resistance and strong restorability. A series of hybrid combinations were carried out.

Then, the first generation of hybrids (a series of hybrid combinations) sowing was conducted in a selective nursery. Herbicides were sprayed at the 4-leaf stage to kill pseudo-hybrids that were not resistant. Then, 3 - 4 plants with good seed and full plants were harvested and threshed for planting in the next year.

From the first generation, after selecting single plants with full anthers and loose powder contents, backcrossing was conducted with K359 and K492 four times to establish the next generation with nuclear replacement. Then, the backcrossed progeny was oriented and selected. After continuous selection for 4 - 5 generations, stable hybrid progeny was selected. After selecting a single plant, the remaining parts of the ear line were mixed and harvested. After two consecutive years of observation of the anther traits, the rows of spikes that meet the requirements of the target traits, anti-sethoxydim recovery lines with full and exposed anthers and a large amount of powder were obtained.

\subsection{Detection of Leaf Age Dynamics in Foxtail Millet Hybrid Parental Lines}

The leaf age dynamics experiment was conducted at the Luannan Research and Experiment Station of Tangshan Normal University from 2016 to 2017. The newly selected sterile lines, DZ759A, KM58A and KM249A, and the restorer 
lines, HK902 and HK950, were used as test materials. First, the restorer and sterile lines were sowed at the same time. Afterward, the sterile line was planted once every day a total of 20 times. During the seeding stage, three representative plants was selected for each sowing period. Each piece of the unfolded leaves was marked with a marker pen. Leaves were subsequently observed, the dates of development for each period were recorded. The sowing rules regarding the sterile and restorer lines that meet during flowering stage were also explored. By tracking and monitoring leaf age development, a dynamic database of leaf age development of the foxtail millet hybrids was established. Based on this, a coupling model of leaf age development of the male and female parental lines was also established.

\subsection{Regulation Technology for the Foxtail Millet Hybrid Parental Lines}

The regulation technology experiment was conducted at the Luannan Millet Research and Experiment Station of Tangshan Normal University from 2016 to 2017. Plot regulation and the seed field control experiments were conducted simultaneously. Flowering regulation of the foxtail millet hybrid parental lines was investigated from three aspects: agronomy, fertilizer and water, and chemical regulation.

The plot experiment was randomly arranged in 14 rows with a row spacing of $0.4 \mathrm{~m}$, row length of $3.5 \mathrm{~m}$, and three replicates. In order to avoid the influence of different control measures, the sterile and restorer lines were planted in a 2:1 ratio in every unit ( 2 sterile lines on both sides and 1 restoring line). The female parent was sowed at 5 days, 2 days before the male parental line, on the same day and at 2 days, 5 days and 10 days after the male parental line with a total of six levels. The seed field control experiment was not repeated and was conducted under the same conditions as the plot test with six levels.

Based on the co-extension relationship between leaf and ear differentiation, four regulatory nodes were established: the maternal 4-leaf stage, which consisted of seedlings that did not rely on seed vegetative growth that exhibited self-sufficient fertility; 8-leaf stage, the earliest stage of panicle differentiation; 12-leaf stage, the beginning of the booting stage; 16-leaf stage, the late booting stage [27].

At each regulatory node, based on the leaf development coupling law of the sterile and restorer lines, agronomic regulation was adopted as follows: development of fast seedlings, delayed thinning time, controlled growth; slow development, accelerated thinning time, big seedling and strong seedling leaves, and growth promotion. Fertilizer and water regulation were as follows: $0.5 \%-1.0 \%$ ammonium bicarbonate water or urea irrigation roots and $0.5 \%-1.0 \%$ potassium dihydrogen phosphate irrigation roots. Hormone regulation was as follows: late parental leaves were sprayed with $2 \times 10^{-5}$ gibberellin and $2 \times 10^{-5}$ naphthalene acetic acid. The regulation effects of various control measures were investi- 
gated to provide technical support and ensure that the parental lines encounter one another during the flowering stage and increased seed production.

\section{Results}

\subsection{Identification and Screening of Foxtail Millet Resources with Some Object Characters}

After two consecutive years of field magnifying inspection and further screening using a microscope in the laboratory, four parental lines with obvious exertion, high exertion rates, and plump stigma were obtained from 300 total breeding materials; they are: 206083, Datong 29, Datong 27 and 1066A (Figure 1). The

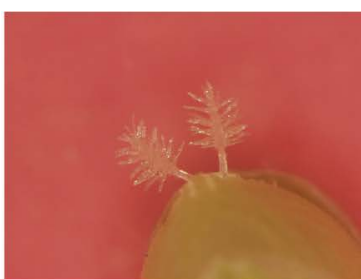

(a)

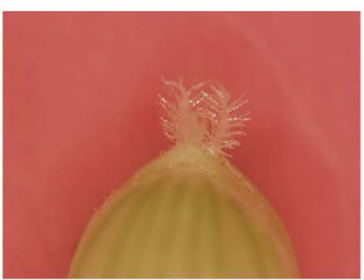

(c)

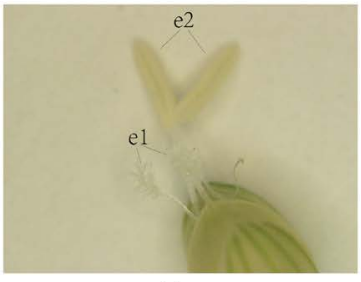

(e)

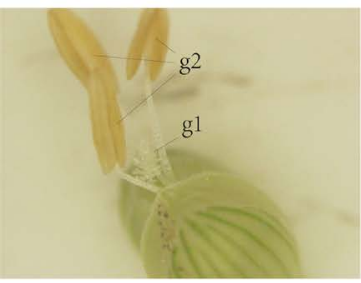

(g)

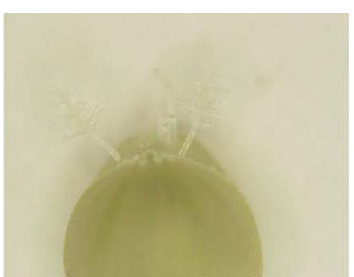

(b)

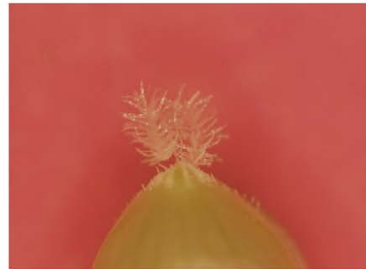

(d)

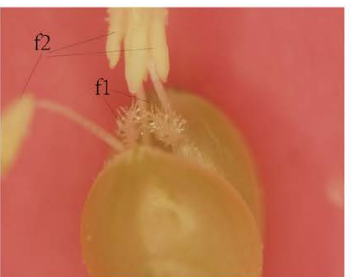

(f)

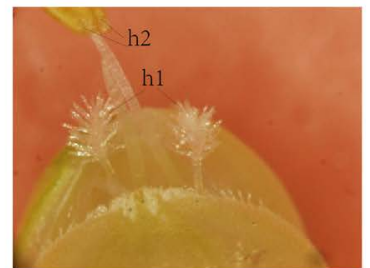

(h)

Figure 1. The organs development of foxtail millet. (a). The stigma development of 206083 in 2007. (b). The stigma development of 206083 in 2008. (c). The stigma development of 1066A in 2007. (d). The stigma development of 1066A in 2008. (e). The development of Datong 27 in 2007, e1. stigma, e2. anther. (f). The development of Datong 27 in 2008, f1. stigma, f2. anther. (g). The development of Datong 29 in 2007, g1. stigma, g2. anther. (h). The development of Datong 29 in 2008, h1. stigma, h2. anther. 
stigma of 206083 were completely exposed and plump with an exposure rate of 85.69\%, Datong 27 stigma were completely exposed and plump with an exposure rate of $77.57 \%$, Datong 29 stigma were completely exposed and moderately plump with an exposure rate of $68.83 \%$, and 1066A stigma were $3 / 4$ exposed and plump with an exposure rate of 78.23\% (Table 1, Table S1-1 and Table S1-2). Collectively, these results indicate that the breeding materials have better stigma development and strong abilities to accept pollen.

Two parental lines with long filaments and anthers that were completely exposed and full were screened; they are Datong 29 and Datong 27 (Figure 1). These lines were used to transfer the recovery line with strong loose powder abilities (Table 2, Table S2-1 and Table S2-2). These findings indicated that Datong 27, Datong 29 stigma and anther development were better and had a high outcrossing rate.

\subsection{Emergence of Foxtail Millet Sterile Lines with Obvious Stigma Exertion, High Exertion Rates, Plump Stigma and Easy Exotic Pollination Acceptance}

Using 1066A as the female parental line and 206083, Datong 27 and Datong 29 as the male parental lines, a series of hybrid combinations were prepared. Then, 206083, Datong 27 and Datong 29 were used as recurrent parents, and generations were subsequently used as experimental materials. After interval generation backcrossing four times and orientation selection, the stigma traits of the offspring were observed. In 2012, the target traits were bred, DZ759A (after the hybrid combination 1066A $\times 206083$ was combined, backcrossed 4 times with

Table 1. The stigma development of 206083, 1066A, Datong 27 and Datong 29.

\begin{tabular}{|c|c|c|c|c|c|c|c|c|c|c|}
\hline \multirow{2}{*}{ Material } & \multicolumn{3}{|c|}{$\begin{array}{c}\text { Stigma exsertion } \\
\text { rate }(\%)\end{array}$} & \multicolumn{3}{|c|}{$\begin{array}{c}\text { Degree of } \\
\text { exposure (\%) }\end{array}$} & \multicolumn{3}{|c|}{ Fullness } & \multirow{2}{*}{ Overview } \\
\hline & 2007 & 2008 & $\begin{array}{l}\text { Mean } \\
\text { Value }\end{array}$ & 2007 & 2008 & $\begin{array}{l}\text { Mean } \\
\text { Value }\end{array}$ & 2007 & 2008 & $\begin{array}{l}\text { Mean } \\
\text { Value }\end{array}$ & \\
\hline 206083 & 86.07 & 85.31 & 85.69 & 100 & 100 & 100 & high & high & high & good \\
\hline $1066 \mathrm{~A}$ & 77.56 & 78.90 & 78.23 & 75 & 83 & 79 & high & high & high & good \\
\hline Datong 27 & 77.46 & 77.67 & 77.57 & 100 & 100 & 100 & medium & medium & medium & good \\
\hline Datong 29 & 68.64 & 69.01 & 68.83 & 100 & 100 & 100 & medium & medium & medium & good \\
\hline
\end{tabular}

Table 2. The anther development of Datong 27 and Datong 29.

\begin{tabular}{|c|c|c|c|c|c|c|c|c|c|c|}
\hline \multirow[b]{2}{*}{ Material } & \multicolumn{3}{|c|}{ Anther exposure rate (\%) } & \multicolumn{3}{|c|}{ Degree of exposure (\%) } & \multicolumn{3}{|c|}{ Fullness } & \multirow[b]{2}{*}{ Overview } \\
\hline & 2007 & 2008 & $\begin{array}{l}\text { Mean } \\
\text { Value }\end{array}$ & 2007 & 2008 & $\begin{array}{l}\text { Mean } \\
\text { Value }\end{array}$ & 2007 & 2008 & $\begin{array}{l}\text { Mean } \\
\text { Value }\end{array}$ & \\
\hline Datong 27 & 76.88 & 76.96 & 76.92 & 100 & 100 & 100 & high & high & high & good \\
\hline Datong 29 & 79.73 & 78.26 & 79.00 & 100 & 100 & 100 & high & high & high & good \\
\hline
\end{tabular}


206083), KM58A (after the hybrid combination 1066A $\times$ Datong 27 was combined, backcrossed 4 times with Datong 27) and sterile lines including KM249A (after combining 1066A $\times$ Datong 29, using Datong 29 to backcross 4 times). Then, from 2013 to 2014, the stigma traits of these sterile lines were further observed for two consecutive years and "DZ759A, KM58A, KM249A" were determined to be the new types of sterile lines with the created stigma and other target traits (Figure 2; Table 3, Table S3-1 and Table S3-2).

\subsection{Emergence of Foxtail Millet Restoration Lines with Exposed and Full Anthers and Strong Powder-Removing Ability}

Using Datong 27 and Datong 29 as the female parental lines, while K359 and K492 as the male parental lines, a series of hybrid combinations were prepared. Then, K359 and K492 were used as recurrent parents, backcrossing was conducted

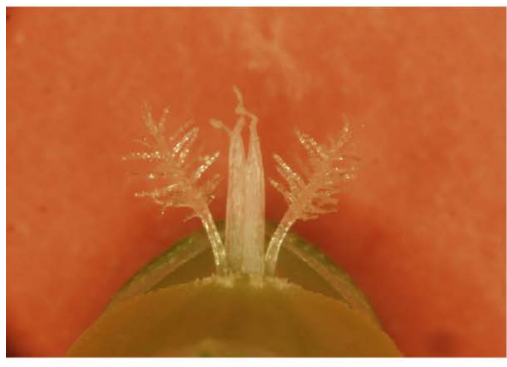

(a)

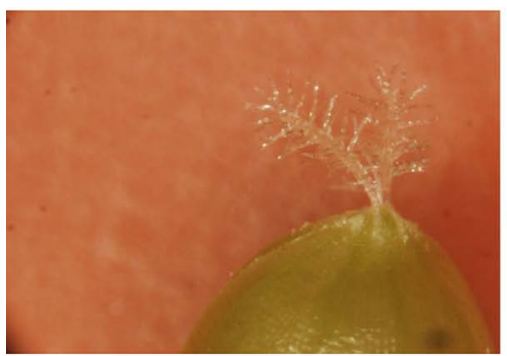

(c)

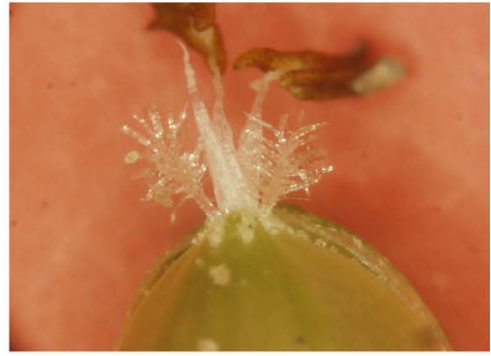

(e)

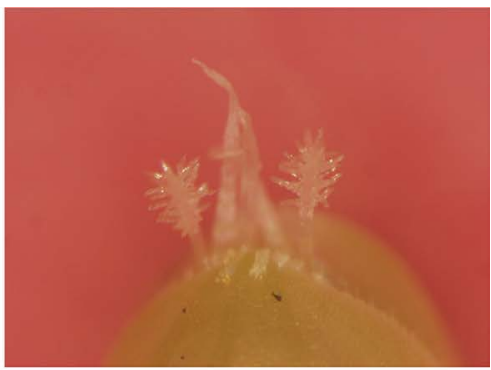

(b)

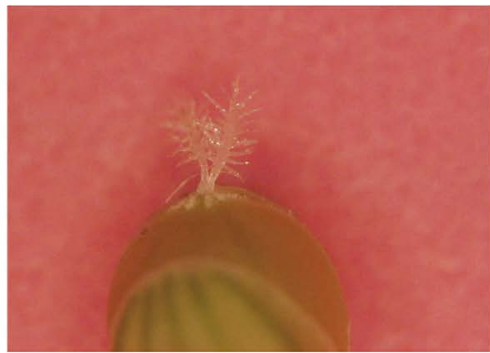

(d)

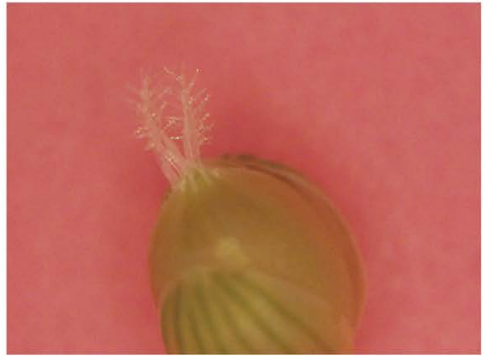

(f)

Figure 2. The stigma development of foxtail millet. (a). The stigma development of DZ759A in 2013. (b). The stigma development of DZ759A in 2014. (c). The stigma development of KM249A in 2013. (d). The stigma development of KM249A in 2014. (e). The stigma development of KM58A-1 in 2013. (f). The stigma development of KM58A-1 in 2014. 
Table 3. The stigma development of DZ759A, KM58A and KM249A.

\begin{tabular}{lccccccccccc}
\hline & \multicolumn{3}{c}{ Stigma exsertion rate (\%) } & \multicolumn{2}{c}{ Degree of exposure (\%) } & \multicolumn{3}{c}{ Fullness } & Overview \\
\cline { 2 - 11 } Material & 2013 & 2014 & $\begin{array}{l}\text { Mean } \\
\text { Value }\end{array}$ & 2013 & 2014 & $\begin{array}{l}\text { Mean } \\
\text { Value }\end{array}$ & 2013 & 2014 & $\begin{array}{l}\text { Mean } \\
\text { Value }\end{array}$ \\
\hline DZ759A & 82.92 & 82.82 & 82.87 & 100 & 100 & 100 & high & high & high & good \\
KM58A & 79.63 & 78.89 & 79.26 & 100 & 100 & 100 & high & high & high & good \\
KM249A & 74.26 & 74.94 & 74.60 & 100 & 100 & 100 & high & high & high & good \\
\hline
\end{tabular}

four times. After orientation selection for anther traits, in 2012, the outstanding target traits were bred HK902 (after combining Datong $27 \times$ K359, backcrossed 4 times with K359), HK950 (after combining Datong $29 \times$ K492, backcrossed 4 times with K492), etc. Then, from 2013 to 2014, the anther traits of these restorer lines were observed for two consecutive years, while "HK902, HK950" were determined to be the new restorer lines with target traits, such as anthers, that met the requirements (Figure 3; Table 4, Table S4-1 and Table S4-2).

\subsection{Detection and Coupling Law of Leaf Age Dynamics in Foxtail Millet Hybrid Parental Lines}

From 2016 to 2017, the tracking and monitoring results of the leaf developmental dynamics of the sterile lines, DZ759A, KM58A and KM249A, while the restoration lines, HK902 and HK950, revealed that in Luannan and similar ecological areas, when DZ759 and HK902 were the parental lines of the hybrid seeds, 2 4 days after the male parental lines advanced sowing the female parental lines, the parental lines encountered one another during the flowering stage; 3 days is the most conducive time for encounters during the flowering stage. When the DZ759 and HK950 group were the parent lines of the hybrid seeds, the male parental lines encountered the female parental lines 3 - 5 days in advance; 4 days is the most conducive time for encounters during the flowering stage. When the KM58A, KM249A and HK902 groups were prepared, the male parental lines encountered the female parental lines 9 - 15 days in advance. When the KM58A, KM249A and HK950 groups were prepared, the male parental lines encountered the female parental lines 10 - 18 days in advance. Additionally, due to the sterile line's sensitive light-temperature response, the leaves of the sterile lines, DZ759A, KM58A and KM249A, exhibited a decreasing trend as the sowing date was delayed, but this trend was not regular. The temperature was high enough during the sowing period and the leaves were not reduced. After further analysis of the developmental dynamics of leaf age at suitable sowing dates, the relationship between the parent control nodes was determined (Figure 4 and Figure S1; Table 5, Table S5 and Table S6).

\subsection{Regulation Techniques for Foxtail Millet Hybrid Parental Lines}

From 2016 to 2017, the research on the regulation of the flowering period of 
Table 4. The anther development of HK902 and HK950.

\begin{tabular}{lccccccccccc}
\hline & \multicolumn{1}{c}{ Anther exposure rate (\%) } & \multicolumn{1}{c}{ Degree of exposure (\%) } & \multicolumn{3}{c}{ Fullness } \\
\cline { 2 - 8 } Material & 2013 & 2014 & $\begin{array}{l}\text { Mean } \\
\text { Value }\end{array}$ & 2013 & 2014 & $\begin{array}{l}\text { Mean } \\
\text { Value }\end{array}$ & 2013 & 2014 & $\begin{array}{l}\text { Mean } \\
\text { Value }\end{array}$ & \\
\hline HK902 & 77.13 & 77.19 & 77.16 & 100 & 100 & 100 & high & high & high & good \\
HK950 & 78.13 & 77.86 & 78.00 & 100 & 100 & 100 & high & high & high & good \\
\hline
\end{tabular}

Table 5. The relationship of leaves on control nodes between the sterile lines (DZ759A, KM58A and KM249A) and the restorer lines (HK902 and HK950).

\begin{tabular}{|c|c|c|c|c|c|c|c|c|c|c|c|c|}
\hline \multirow{3}{*}{ Restorer } & \multicolumn{12}{|c|}{ Sterile line } \\
\hline & \multicolumn{4}{|c|}{$\begin{array}{c}\text { DZ759A } \\
\text { (The number of } \\
\text { expanded leaves) }\end{array}$} & \multicolumn{4}{|c|}{$\begin{array}{c}\text { KM58A } \\
\text { (The number of } \\
\text { expanded leaves) }\end{array}$} & \multicolumn{4}{|c|}{$\begin{array}{c}\text { KM249A } \\
\text { (The number of } \\
\text { expanded leaves) }\end{array}$} \\
\hline & 4 & 8 & 12 & 16 & 4 & 8 & 12 & 16 & 4 & 8 & 12 & 16 \\
\hline $\begin{array}{l}\text { HK902 (The } \\
\text { number of } \\
\text { expanded } \\
\text { leaves) }\end{array}$ & $5-6$ & $8-1$ & $13-141$ & $7-18$ & $7-9$ & $11-$ & $16-17$ & $19-20$ & $7-8$ & $11-$ & $16-17$ & $19-20$ \\
\hline $\begin{array}{l}\text { HK950 (The } \\
\text { number of } \\
\text { expanded } \\
\text { leaves) }\end{array}$ & $5-6$ & $9-1$ & $13-141$ & $7-18$ & $8-9$ & 12 - & $16-172$ & $20-21$ & $8-9$ & $12-$ & $16-17$ & $20-21$ \\
\hline
\end{tabular}

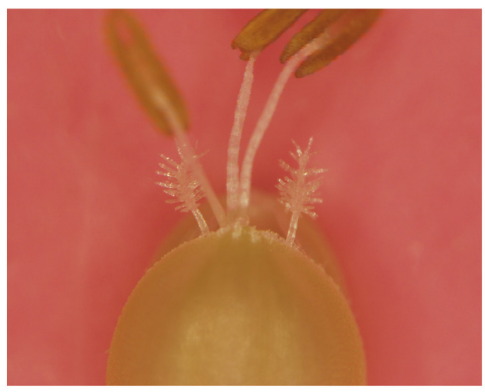

(a)

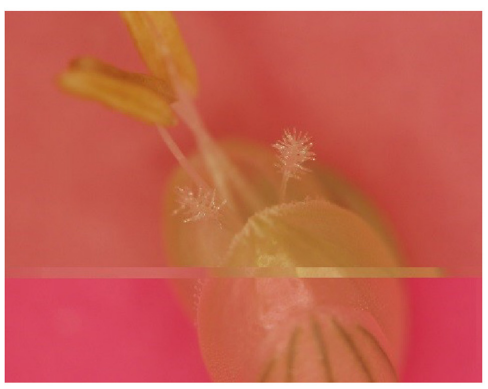

(c)

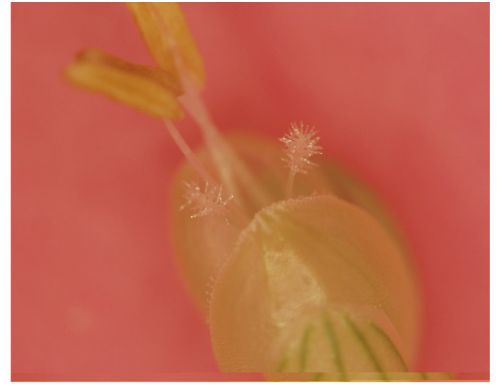

(b)

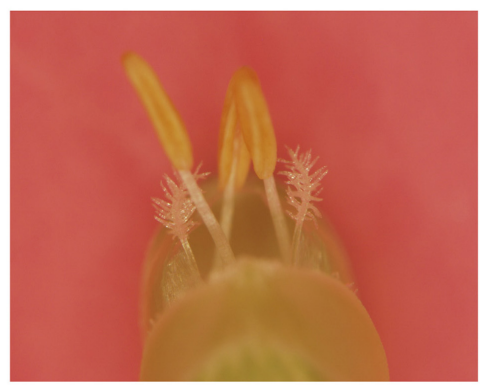

(d)

Figure 3. The anther development of foxtail millet. (a). The stigma development of HK902 in 2013. (b). The stigma development of HK902 in 2014. (c). The stigma development of HK950 in 2013. (d). The stigma development of HK950 in 2014. 


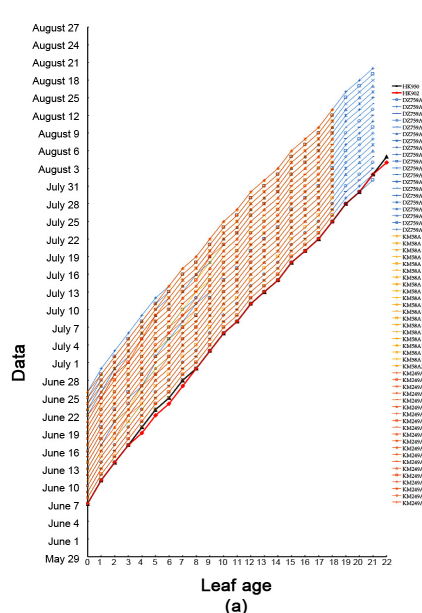

(a)
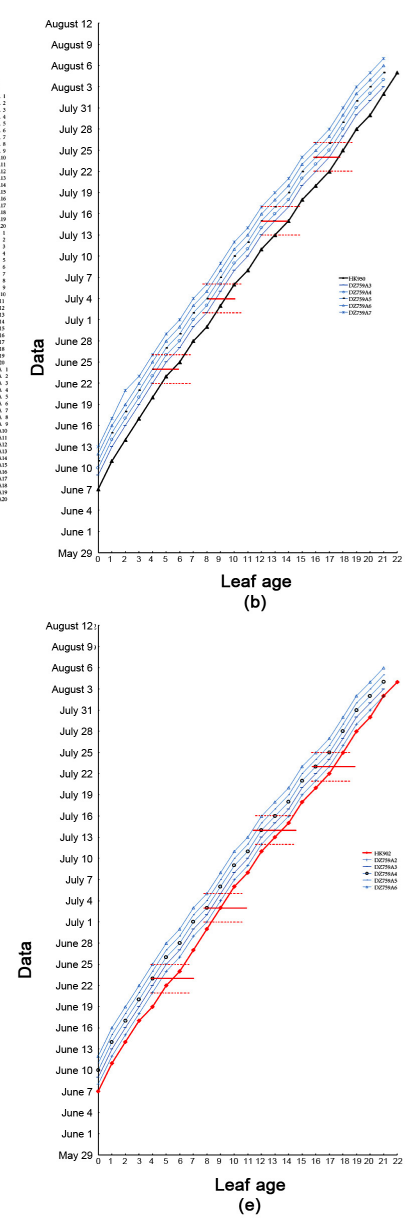
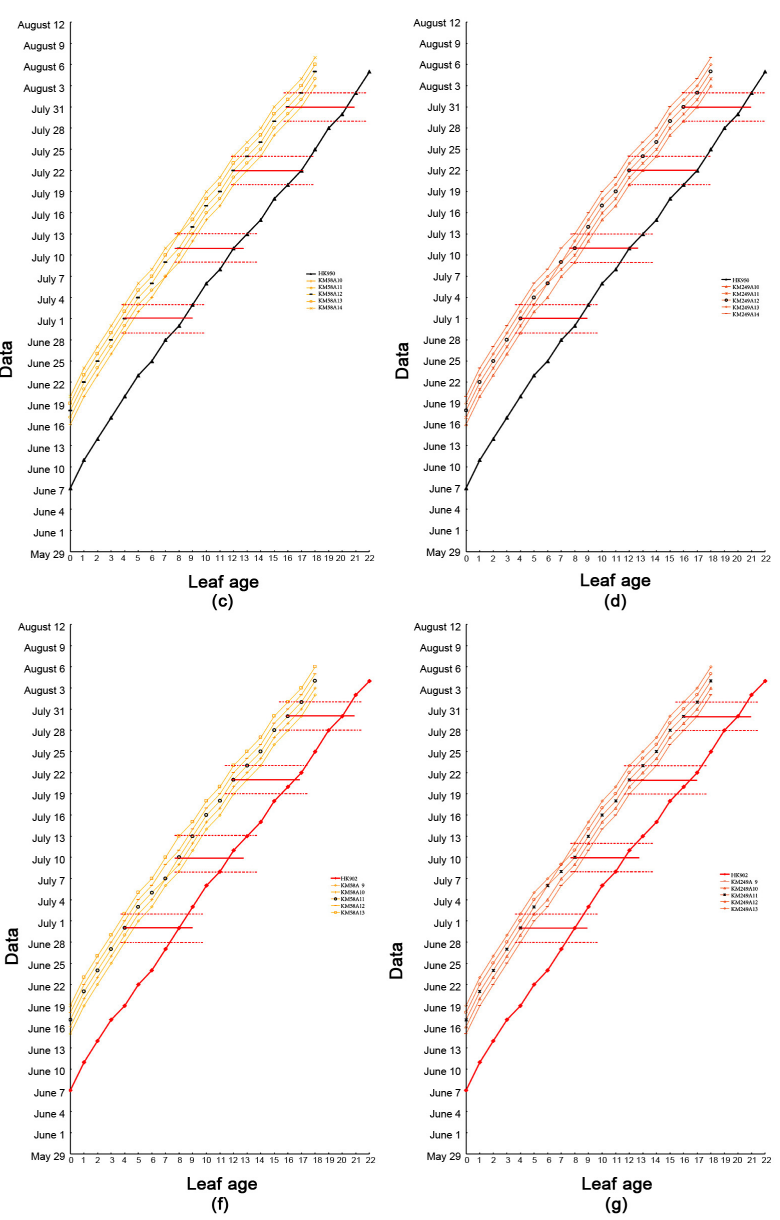

(d)

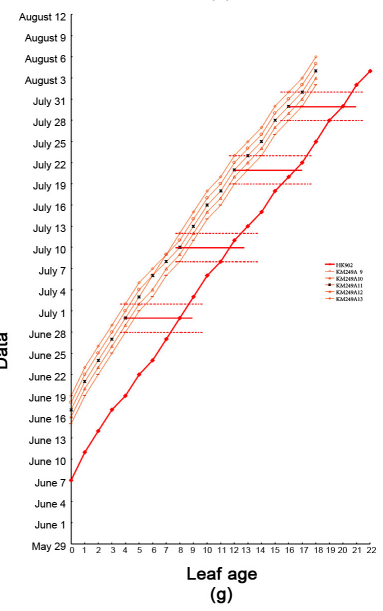

Figure 4. The developmental dynamics of leaf age and the corresponding maps of different control nodes of the sterile lines (DZ759A, KM58A and KM249A) and restorer lines (HK902 and HK950) during 2016 (The graph's horizontal axis shows the leaf age of the tested material, and the vertical axis shows the sowing date and the leaf development date). (a). Developmental dynamics of leaf age of the sterile lines (DZ759A, KM58A and KM249A) and restorer lines (HK902 and HK950) during 2016. (b). The control nodes of the restorer line (HK950) and sterile lines (DZ759A). (c). The control nodes of the restorer line (HK950) and sterile lines (KM58A). (d). The control nodes of the restorer line (HK950) and sterile lines (KM249A). (e). The control nodes of the restorer line (HK902) and sterile lines (DZ759A). (f). The control nodes of the restorer line (HK902) and sterile lines (KM58A). (g). The control nodes of the restorer line (HK902) and sterile lines (KM249A).

sterile lines and restorer lines achieved the following results:

The flowering regulation results revealed that during the seedling 4-leaf stage, there was uncoordinated growth in the female and male parental lines. Thus, it is necessary to adopt agronomic measures to regulate and control the growth of parental seedlings. For fast-developing parental lines, seedlings underwent delayed thinning and leaves of small seedlings were used to control growth. For slow-developing parental lines, seedlings were thinned in advance and leaves of big and strong seedlings were used to promote growth.

At the 8-leaf stage, uncoordinated parental growth was observed, but the development of parental lines was not noticeably different (1 - 2 leaves). Plants were regulated by fertilizer and water treatments, and early-developing parental lines rooted in $0.5 \%-1.0 \%$ urea solutions, an appropriate extension of vegetative 
growth. For late-developing parental lines, $0.5 \%-1.0 \%$ potassium dihydrogen phosphate was used to accelerate reproductive growth. If the development of the parental lines was considerably different (up to four leaves), it was necessary to conduct artificial root-cutting. When the roots were broken, $1 / 3$ of the root system was cut obliquely at $5 \mathrm{~cm}$ along the base of the foxtail millet stalk and were uncoordinated at $45^{\circ}$. The next day, the leaves appeared mildly wilted and regulation was achieved.

At the 12-leaf stage, uncoordinated flowering was observed and hormone regulation was used. When the difference was not large, the upper leaves of the late-developing parental lines, were sprayed with $2 \times 10^{-5}$ gibberellin solution; and the difference between the parental lines was greater than 10 days (3 - 4 leaves). Plants were sprayed once every 24 hours and continuously sprayed three times. When the difference between the parental lines was within 10 days, the number of applications was reduced and the medication time was prolonged. Afterwards, foliar spray fertilizer consisted of $0.5 \%$ potassium dihydrogen phosphate and $1 \%$ urea to ensure the normal development of new leaves and tassels.

At the 16-leaf stage, the parental flowering period was uncoordinated. The $2 \times$ $10^{-5}$ naphthalene acetic acid solution was used to spray late-developing parental leaves. The difference of the parental lines was about 10 days in the flowering stage, as flowering can anastomosis after hormone regulation. However, more than 15 days must be adjusted by agronomic measures for plants to conduct artificial root-cutting.

\section{Discussion}

Previous studies demonstrated that stigma and anther traits are qualitative traits or quantitative traits with high heritability, and their characteristics are not greatly affected by the environment [16] [17] [18] [19] [20]. In this study, two annual trials were established. Based on the results, the new sterile lines and restorer lines that were bred indeed met the requirements of the breeding goals, indicating that the experimental results of this study are reliable.

The stigma traits of the sterile lines determine the ability of the sterile lines to accept foreign pollen, and the anther characteristics of the restorer lines determine the pollen characteristics of the restorer lines. The stigma traits of the sterile lines and the anther characteristics of the restorer lines can be inherited; previous studies found part of a QTL that controls stigma and anther traits [28] [29] [30] [31]. Only by creating a sterile line with full stigma, obvious exposure, and high exposure rate, can the sterile line's ability to accept foreign pollen be improved. Additionally, it is necessary to create a restorer line with full anthers and full exposure to protect the glume in order to improve the heterogeneity of the sterile line. The seed setting rate, in turn, increases the seed yield. Thus, this project began with the transformation of the floral characteristics of the sterile and restorer lines of millet. Through the creation of a sterile line that is easy to 
accept foreign pollen and a restorer line with strong powder dispersing ability, the outcrossing seed setting rate of millet was improved, and the stigma traits and stigma of the sterile line were further improved. The heritability of the anther traits of the restorer line was complementary to a previous conclusion that the stigma and anther traits are qualitative traits or quantitative traits with higher heritability, and thus mutually verify each other.

Many researchers have attempted to increase the seed yields of foxtail millet hybrids by various methods, such as the selection and application of photo-thermophilic male sterile lines [10]. In the cold-growing hilly area of a seed production site [11] and some cultivation method such as sowing within a certain time interval etc. [12] [13]. However, the photo-thermophilic male sterile line exhibits infertility in cold environments, such as the long-term cold zone of Northern China. Comparatively, fertility in the short-day, high-temperature zone of Southern China was greatly improved [10]. Light and temperature can maintain the sterile line and improve it, but the ability of the sterile line to receive pollen is minimal. Meanwhile, production in the shallow hills area and reducing the planting ratio of the female to male, which extended the time for receiving pollen and decreased the distance that the male's loose powder needed to travel. However, these effects on seed production were limited. Due to foxtail millet's sensitivity to light and temperature, even if sowing was conducted within a certain time interval, based on the growth and development regulation of the hybrids' parents, climatic conditions during the growth period still play an important role. Thus, the flowering stage will not be synchronized and production is thereby reduced. Moreover, even if these methods ensured that the parental lines encountered one another during the flowering stage, outcrossing rates have not been improved, and foxtail millet hybrid seed production was difficult to increase, and foxtail millet hybrid seed production was difficult to increase, which was generally less than $1500 \mathrm{~kg} / \mathrm{hm}^{2}$ [2]. A few reports were available on the creation of sterile lines with high stigma exposure rates and no restorer lines with high outcrossing rates in foxtail and other crops. In this study, Datong 27, Datong 29 and gu 83 were screened and identified through meticulous observations of their pollination habitats. The three resources possess object characteristics. We transformed into a series of stigma-exposed and plump sterile lines that easily accepted exotic pollen (DZ759A, KM58A, KM249A); and new restorer lines with anthers that were full of powder and exhibited quick recovery (HK950, HK902), which improved the parental lines' heterosexual characteristics, and improved outcrossing rate of the sterile line, and laid a foundation for increasing seed yield of foxtail millet hybrid.

Based on the above findings, this study adopted the tracking and detection of leaf age development dynamics to detect and confirm the coupling law of leaf age development in the meeting during the flowering stage of foxtail millet hybrid parental lines, and based on the co-extension relationship between leaf development and ear differentiation, four regulatory nodes that ensured that the 
parental lines encountered one another were summarized through a series of regulation and control measures. These technologies belonged to previous studies on the coextensive relationship between leaf development and panicle differentiation [23] [24] and further research and application in hybrid seed production technology, which can effectively ensure the self-pollination of millet, which is sensitive to light and temperature. In the process of crop hybrid seed production, the parents meet during the flowering stage, thereby increasing seed yield. Applied in practice, good results were achieved. On August 26 and 27, 2016, the Hebei Provincial Department of Science and Technology organized experts to conduct an on-site inspection of $1.67 \mathrm{hm}^{2}$ farmland in Xindian Village, Luojiatun Town, Qianxi County, China, and adopted random sampling methods. Results revealed that the average yield of seed yield was $3019.8 \mathrm{~kg} / \mathrm{hm}^{2}$, thus overcoming the bottleneck that previously restricted the cultivation of foxtail millet hybrids and laying a foundation for the large-scale extension of foxtail millet hybrids.

\section{Funding}

This work was supported by the S \& T Program of Hebei (16226310D), S \& T Program of Hebei (18226350), Key Research and Development Project of Tangshan (19150229E), and Scientific Research Fund of Tangshan Normal University (2020C01).

\section{Author Contributions}

ZL and SL contributed to the study conception and design. ZL, QL, SY and XZ performed the experiments. DL, YC and SL analyzed the data. ZL and GM wrote the manuscript. All authors read and approved the final manuscript.

\section{Conflicts of Interest}

The authors declare that they have no conflict of interest.

\section{References}

[1] Zhang, J., Zhang, G. and Liu, B. (2010) Demonstration and Analysis of Zhanggu in Chengde. Hebei Agriculture, 6, 13-14.

[2] Li, S.Y., Liu, D., Li, Q., Chen, C. and Liu, Z.L. (2018) Breeding of Advantage Heterosis Foxtail Millet Hybrid Jizagu5 with Characteristic of Herbicide-Resistant and the Research of Simplified Cultivation Technique in Seedlings. Journal of Tangshan Normal University, 40, 54-58.

[3] Mo, K.S. (2010) Flowering Prediction and Regulation Technology for Hybrid Rice Seed Production. Journal of Guangxi Agriculture, 4, 37-39.

[4] Li, W., Zhi, H., Wang, Y.F., Li, H.Q. and Diao, X.M. (2012) Assessment of Genetic Relationship of Foxtail Millet with Its Wild Ancestor and Close Relatives by ISSR Markers. Journal of Integrative Agriculture, 11, 556-566. https://doi.org/10.1016/S2095-3119(12)60042-2

[5] Ji, G.S., Du, R.H., Hou, S.L., Cheng, R.H., Wang, X.Y. and Zhao, X.Y.(2007) Genet- 
ics, Development and Application of Cytoplasmic Herbicide Resistance in Foxtail Millet. Agricultural Sciences in China, 6, 779-785. https://doi.org/10.1016/S1671-2927(07)60112-6

[6] Wang, T.Y. and Darmency, H. (1997) Inheritance of Sethoxydim Resistance in Foxtail Millet, Setaria italica (L.) Beauv. Euphytica, 94, Article No. 69. https://doi.org/10.1023/A:1002989725995

[7] Wang, T.Y., Fleury, A., Ma, J. and Darmency, H. (1996) Genetic Control of Dinitroaniline Resistance in Foxtail Millet (Setaria italica). Journal of Heredity, 87, 423-426. https://doi.org/10.1093/oxfordjournals.jhered.a023031

[8] Ding, Y.D., Nie, S.H., Wang, X., Hu, X.W., Feng, G.J., Geng, H.W. and Zhan, S.S. (2018) Genetic Diversity of Agronomic Traits of Foxtail Millet (Setaria italic (L.) Beauv.) Mainly Bred Varieties in Xinjiang Province, China. Journal of Plant Genetic Resources, 19, 232-242.

[9] Li, D.H. and Wang, Y.Q. (1986) Improvement of Millet Quality. Crops, 3, 4-6.

[10] Wang, Y.W., Wang, S.B., Li, H.X., Wang, G.H., Tian, G. and Shi, Q.X. (2003) Studies on Breeding of Photoperiod-Sensitive Male-Sterile Line in Millet and Its Application. Crops, 6, 714-717.

[11] Li, X.M. (1998) High Quality and High Yield Maize Seed Production Technology in Western Henan. Seed Science \& Technology, 5, 33-34.

[12] Tong, X.L., Li, G.H., Zhao, H.J., Cao, R.X., Zhang, H.J. and Jiang, X.P. (2000) Influence of Different Density and Row Ratios of Parents for Ningza No. 1 on the Seed Yield. Journal of Nanjing Agricultural Technology College, 4, 25-28.

[13] Shi, G.Y., Yang, C.Y., Shi, G.S., Ma, H.F. and Hou, G.L. (2012) Breeding and Seed Production Technology of New Millet Hybrid Variety Jingu49. Crops, 5, 112-113.

[14] Sun, Z., Mo, Q.C., Cheng, B.J., Xie, C.X. and Lin, F. (2012) Heredity of Tassel Branch Number Character in Maize. Crops, 2, 31-35.

[15] Duan, Z.F. and Zhang, E.R. (1988) New Method for Regulating Flowering Period in Sorghum Upland Planting Field. Journal of Shanxi Agricultural Sciences, 4, 22.

[16] Yang, W. and Li, D. (2006) Preliminary Genetics Study on Rice Stigma Exertion. Proceeding of the Workshop on Research and Development of Biotechnology, Hainan, 110.

[17] Li, T. and Chen, Y. (1987) Genetic Study on Stigma Extrusion of Rice. Crops, 13, 314-321.

[18] Virmani, S. and Athwal, D. (1974) Inheritance of Floral Characteristics Influencing Outcrossing in Rice. Crop Science, 14, 350-353.

https://doi.org/10.2135/cropsci1974.0011183X001400030002x

[19] Wu, S., Li, C., Wang, S., Yang, R. and Zhang, S. (2003) Heritable and Correlation Analysis of Several Restore Line's Floral Character. Journal of Anhui Agricultural Sciences, 31, 171-173.

[20] Yu, T., Zhang, L., Hu, Z., Song, W., Liu, S., Zhang, A. and Zhu, Y. (2003) Genetic Analysis of Floral Characters in ADH Population Derived from an Indica/Japonica Cross of Rice. Journal of Wuhan Botanical Research, 21, 459-463.

[21] Liang, S.H., Li, C.G, Wu, Y.Y., Wang, F. and Fu, F.H. (1999) Path Analysis of Yield Components in Hybrid rice. Guangdong Agricultural Sciences, 6, 4-6.

[22] Yuan, F., Yang, H.Q., Wang, J. and Guo, E.H. (2010) Principal Component Analysis of Yield-Related Characters in Millet. Journal of Hebei Agricultural Sciences, 14, 112-114. 
[23] Liang, X.L. and Zhang, Z.H. (1995) Study on the Relationship between Ear Differentiation and Leaf Age in Maize. Journal of South China Agricultural University, 3, 83-87.

[24] Wei, Y.C. and Zhu, Q.S. (1982) The Relationship of Maize Ear Differentiation Period with Nutrition and Reproductive Organs and Its Significance in Production Practice. Journal of Henan Institute of Science and Technology, 2, 36-43.

[25] Chen, J.S., Ding, J.Q., Gao, J.B. and Fu, Z.H. (1992). Regulation of Several Novel Hormones in Hybrid Rice Seed Production. Seed Science \& Technology, 5, 32-33.

[26] Liu, D.Q. (1993) Method for Prediction and Adjustment of Flowering Period in Maize Seed Production. Seed World, 8, 34.

[27] Xin, S.F. and Zhao, F. (1981) Foxtail Millet Leaf Age and Young Ear Differentiation. Modern Agriculture, 2, 42-46.

[28] Li, C., Sun, C., Mu, P., Chen, L. and Wang, X. (2001) QTL Analysis of Anther Length and Ratio of Stigma Exsertion, Two Key Traits of Classification for Cultivated Rice (Oryza sativa L.) and Common Wild Rice (O. rufipogon Griff.). Acta Genetica Sinica, 28, 746-751.

[29] Li, P., Feng, F., Zhang, Q., Chao, Y., Gao, G. and He, Y. (2014) Genetic Mapping and Validation of Quantitative Trait Loci for Stigma Exsertion Rate in Rice. Molecular Breeding, 34, 2131-2138. https://doi.org/10.1007/s11032-014-0168-2

[30] Xiong, L., Liu, K., Dai, X., Xu, C. and Zhang, Q. (1999) Identification of Genetic Factors Controlling Domestication-Related Traits of Rice Using an F2 Population of a Cross between Oryza sativa and O. rufipogon. Theoretical Applied Genetics, 98, 243-251. https://doi.org/10.1007/s001220051064

[31] Yan, W., Li, Y., Agrama, H.A., Luo, D., Gao, F., Lu, X. and Ren, G. (2009) Association Mapping of Stigma and Spikelet Characteristics in Rice (Oryza sativa L.). Molecular Breeding, 24, 277-292. https://doi.org/10.1007/s11032-009-9290-y 


\section{Supplementary Materials}

Table S1-1. The statistical results of stigma exposure rate of 206083, 1066A, Datong 27 and Datong 29 in 2007.

\begin{tabular}{|c|c|c|c|c|c|c|c|c|}
\hline Material & Repeat & Part & $\begin{array}{l}\text { The number of } \\
\text { exposed small flowers } \\
\text { in each column }\end{array}$ & $\begin{array}{l}\text { Total number } \\
\text { of small flowers } \\
\text { in each part }\end{array}$ & $\begin{array}{l}\text { Total number of } \\
\text { exposed small flowers } \\
\text { on the stigma }\end{array}$ & $\begin{array}{c}\text { Total number } \\
\text { of small } \\
\text { flowers }\end{array}$ & $\begin{array}{l}\text { Single column } \\
\text { head exposure } \\
\text { rate }(\%)\end{array}$ & $\begin{array}{l}\text { Stigma } \\
\text { exsertion } \\
\text { rate (\%) }\end{array}$ \\
\hline \multirow{9}{*}{206083} & \multirow{3}{*}{$\begin{array}{c}\text { First } \\
\text { strain }\end{array}$} & Above & 62 & 69 & \multirow{3}{*}{179} & \multirow{3}{*}{201} & \multirow{3}{*}{89.05} & \multirow{9}{*}{86.07} \\
\hline & & Middle & 69 & 75 & & & & \\
\hline & & Below & 48 & 57 & & & & \\
\hline & \multirow{3}{*}{$\begin{array}{l}\text { Second } \\
\text { strain }\end{array}$} & Above & 58 & 71 & \multirow{3}{*}{182} & \multirow{3}{*}{209} & \multirow{3}{*}{87.08} & \\
\hline & & Middle & 73 & 76 & & & & \\
\hline & & Below & 51 & 62 & & & & \\
\hline & \multirow{3}{*}{$\begin{array}{l}\text { Third } \\
\text { strain }\end{array}$} & Above & 52 & 68 & \multirow{3}{*}{167} & \multirow{3}{*}{203} & \multirow{3}{*}{82.27} & \\
\hline & & Middle & 66 & 74 & & & & \\
\hline & & Below & 49 & 61 & & & & \\
\hline \multirow{9}{*}{$1066 \mathrm{~A}$} & \multirow{3}{*}{$\begin{array}{c}\text { First } \\
\text { strain }\end{array}$} & Above & 53 & 67 & \multirow{3}{*}{162} & \multirow{3}{*}{208} & \multirow{3}{*}{77.88} & \multirow{6}{*}{77.56} \\
\hline & & Middle & 61 & 74 & & & & \\
\hline & & Below & 48 & 67 & & & & \\
\hline & \multirow{3}{*}{$\begin{array}{l}\text { Second } \\
\text { strain }\end{array}$} & Above & 49 & 63 & \multirow{3}{*}{159} & \multirow{3}{*}{197} & \multirow{3}{*}{80.71} & \\
\hline & & Middle & 57 & 68 & & & & \\
\hline & & Below & 53 & 66 & & & & \\
\hline & \multirow{3}{*}{$\begin{array}{l}\text { Third } \\
\text { strain }\end{array}$} & Above & 43 & 61 & \multirow{3}{*}{143} & & & \\
\hline & & Middle & 54 & 68 & & 193 & 74.09 & \\
\hline & & Below & 46 & 64 & & & & \\
\hline & & Above & 48 & 59 & & & & \\
\hline & $\begin{array}{c}\text { First } \\
\text { strain }\end{array}$ & Middle & 55 & 70 & 147 & 190 & 77.36 & \\
\hline & & Below & 44 & 61 & & & & \\
\hline & & Above & 45 & 56 & & & & \\
\hline Datong 27 & $\begin{array}{l}\text { Second } \\
\text { strain }\end{array}$ & Middle & 56 & 67 & 148 & 184 & 80.43 & 77.46 \\
\hline & & Below & 47 & 61 & & & & \\
\hline & & Above & 42 & 51 & & & & \\
\hline & $\begin{array}{l}\text { Third } \\
\text { strain }\end{array}$ & Middle & 51 & 66 & 135 & 181 & 74.59 & \\
\hline & & Below & 42 & 64 & & & & \\
\hline & & Above & 37 & 63 & & & & \\
\hline & $\begin{array}{l}\text { First } \\
\text { strain }\end{array}$ & Middle & 52 & 67 & 127 & 189 & 67.20 & \\
\hline & & Below & 38 & 59 & & & & \\
\hline & & Above & 38 & 61 & & & & \\
\hline Datong 29 & $\begin{array}{l}\text { Second } \\
\text { strain }\end{array}$ & Middle & 57 & 69 & 136 & 195 & 69.74 & 68.64 \\
\hline & & Below & 41 & 65 & & & & \\
\hline & & Above & 39 & 63 & & & & \\
\hline & $\begin{array}{l}\text { Third } \\
\text { strain }\end{array}$ & Middle & 54 & 66 & 129 & 187 & 68.98 & \\
\hline & & Below & 36 & 58 & & & & \\
\hline
\end{tabular}


Q. Li et al.

Table S1-2. The statistical results of stigma exposure rate of 206083, 1066A, Datong 27 and Datong 29 in 2008.

\begin{tabular}{|c|c|c|c|c|c|c|c|c|}
\hline Material & Repeat & Part & $\begin{array}{l}\text { The number of } \\
\text { exposed small } \\
\text { flowers in each } \\
\text { column }\end{array}$ & $\begin{array}{c}\text { Total number } \\
\text { of small } \\
\text { flowers in } \\
\text { each part }\end{array}$ & $\begin{array}{l}\text { Total number of } \\
\text { exposed small } \\
\text { flowers on } \\
\text { the stigma }\end{array}$ & $\begin{array}{c}\text { Total } \\
\text { number of } \\
\text { small } \\
\text { flowers }\end{array}$ & $\begin{array}{c}\text { Single } \\
\text { column head } \\
\text { exposure } \\
\text { rate }(\%)\end{array}$ & $\begin{array}{c}\text { Stigma } \\
\text { exsertion } \\
\text { rate }(\%)\end{array}$ \\
\hline \multirow{9}{*}{206083} & \multirow{3}{*}{ First strain } & Above & 63 & 68 & \multirow{3}{*}{184} & \multirow{3}{*}{211} & \multirow{3}{*}{87.20} & \multirow{9}{*}{85.31} \\
\hline & & Middle & 67 & 76 & & & & \\
\hline & & Below & 54 & 67 & & & & \\
\hline & \multirow{3}{*}{$\begin{array}{l}\text { Second } \\
\text { strain }\end{array}$} & Above & 57 & 72 & \multirow{3}{*}{181} & \multirow{3}{*}{215} & \multirow{3}{*}{84.19} & \\
\hline & & Middle & 63 & 74 & & & & \\
\hline & & Below & 61 & 69 & & & & \\
\hline & \multirow{3}{*}{$\begin{array}{l}\text { Third } \\
\text { strain }\end{array}$} & Above & 54 & 70 & \multirow{3}{*}{175} & \multirow{3}{*}{207} & \multirow{3}{*}{84.54} & \\
\hline & & Middle & 62 & 71 & & & & \\
\hline & & Below & 59 & 66 & & & & \\
\hline \multirow{9}{*}{$1066 \mathrm{~A}$} & \multirow{3}{*}{ First strain } & Above & 54 & 69 & \multirow{3}{*}{161} & \multirow{3}{*}{203} & \multirow{3}{*}{79.31} & \multirow{9}{*}{78.90} \\
\hline & & Middle & 53 & 71 & & & & \\
\hline & & Below & 54 & 63 & & & & \\
\hline & \multirow{3}{*}{$\begin{array}{l}\text { Second } \\
\text { strain }\end{array}$} & Above & 52 & 67 & \multirow{3}{*}{162} & \multirow{3}{*}{209} & \multirow{3}{*}{77.51} & \\
\hline & & Middle & 55 & 73 & & & & \\
\hline & & Below & 55 & 69 & & & & \\
\hline & \multirow{3}{*}{$\begin{array}{l}\text { Third } \\
\text { strain }\end{array}$} & Above & 44 & 68 & \multirow{3}{*}{151} & & & \\
\hline & & Middle & 51 & 64 & & 189 & 79.89 & \\
\hline & & Below & 56 & 57 & & & & \\
\hline & & Above & 51 & 70 & & & & \\
\hline & First strain & Middle & 57 & 74 & 164 & 215 & 76.28 & \\
\hline & & Below & 56 & 71 & & & & \\
\hline & & Above & 53 & 72 & & & & \\
\hline Datong 27 & $\begin{array}{l}\text { Second } \\
\text { strain }\end{array}$ & Middle & 62 & 74 & 174 & 219 & 79.45 & 77.67 \\
\hline & & Below & 59 & 73 & & & & \\
\hline & & Above & 46 & 62 & & & & \\
\hline & $\begin{array}{l}\text { Third } \\
\text { strain }\end{array}$ & Middle & 58 & 71 & 153 & 198 & 77.27 & \\
\hline & & Below & 49 & 65 & & & & \\
\hline & & Above & 46 & 64 & & & & \\
\hline & First strain & Middle & 47 & 70 & 135 & 201 & 67.16 & \\
\hline & & Below & 44 & 67 & & & & \\
\hline & & Above & 52 & 70 & & & & \\
\hline Datong 29 & $\begin{array}{l}\text { Second } \\
\text { strain }\end{array}$ & Middle & 50 & 73 & 146 & 212 & 68.87 & 69.01 \\
\hline & & Below & 44 & 69 & & & & \\
\hline & & Above & 47 & 64 & & & & \\
\hline & $\begin{array}{l}\text { Third } \\
\text { strain }\end{array}$ & Middle & 57 & 75 & 147 & 207 & 71.01 & \\
\hline & & Below & 43 & 68 & & & & \\
\hline
\end{tabular}


Table S2-1. The statistical results of anther exposure rate of Datong 27 and Datong 29 in 2007.

\begin{tabular}{|c|c|c|c|c|c|c|c|c|}
\hline Material & Repeat & Part & $\begin{array}{l}\text { Number of exposed } \\
\text { small flowers in various } \\
\text { parts of the valley }\end{array}$ & $\begin{array}{l}\text { Total number of } \\
\text { small flowers in } \\
\text { each part }\end{array}$ & $\begin{array}{l}\text { Anthers exposed } \\
\text { total number of } \\
\text { small flowers }\end{array}$ & $\begin{array}{c}\text { Total number } \\
\text { of small } \\
\text { flowers }\end{array}$ & $\begin{array}{l}\text { Single anther } \\
\text { exposure } \\
\text { rate }(\%)\end{array}$ & $\begin{array}{l}\text { Anther } \\
\text { exposure } \\
\text { rate (\%) }\end{array}$ \\
\hline \multirow{9}{*}{ Datong 27} & \multirow{3}{*}{$\begin{array}{c}\text { First } \\
\text { strain }\end{array}$} & Above & 45 & 59 & \multirow{3}{*}{148} & \multirow{3}{*}{190} & \multirow{3}{*}{78.07} & \multirow{9}{*}{76.88} \\
\hline & & Middle & 53 & 70 & & & & \\
\hline & & Below & 50 & 61 & & & & \\
\hline & \multirow{3}{*}{$\begin{array}{l}\text { Second } \\
\text { strain }\end{array}$} & Above & 45 & 56 & \multirow{3}{*}{143} & \multirow{3}{*}{184} & \multirow{3}{*}{77.83} & \\
\hline & & Middle & 52 & 67 & & & & \\
\hline & & Below & 46 & 61 & & & & \\
\hline & \multirow{3}{*}{$\begin{array}{l}\text { Third } \\
\text { strain }\end{array}$} & Above & 40 & 51 & \multirow{3}{*}{135} & \multirow{3}{*}{181} & \multirow{3}{*}{74.73} & \\
\hline & & Middle & 52 & 66 & & & & \\
\hline & & Below & 43 & 64 & & & & \\
\hline \multirow{9}{*}{ Datong 29} & \multirow{3}{*}{$\begin{array}{c}\text { First } \\
\text { strain }\end{array}$} & Above & 49 & 63 & \multirow{3}{*}{152} & \multirow{3}{*}{189} & \multirow{3}{*}{80.43} & \multirow{9}{*}{79.73} \\
\hline & & Middle & 61 & 67 & & & & \\
\hline & & Below & 42 & 59 & & & & \\
\hline & \multirow{3}{*}{$\begin{array}{l}\text { Second } \\
\text { strain }\end{array}$} & Above & 42 & 61 & \multirow{3}{*}{150} & \multirow{3}{*}{195} & \multirow{3}{*}{76.89} & \\
\hline & & Middle & 62 & 69 & & & & \\
\hline & & Below & 46 & 65 & & & & \\
\hline & \multirow{3}{*}{$\begin{array}{l}\text { Third } \\
\text { strain }\end{array}$} & Above & 45 & 63 & \multirow{3}{*}{153} & \multirow{3}{*}{187} & \multirow{3}{*}{81.87} & \\
\hline & & Middle & 59 & 66 & & & & \\
\hline & & Below & 49 & 58 & & & & \\
\hline
\end{tabular}

Table S2-2. The statistical results of anther exposure rate of Datong 27 and Datong 29 in 2008.

\begin{tabular}{|c|c|c|c|c|c|c|c|c|}
\hline Material & Repeat & Part & $\begin{array}{c}\text { Number of exposed } \\
\text { small flowers in various } \\
\text { parts of the valley }\end{array}$ & $\begin{array}{l}\text { Total number of } \\
\text { small flowers in } \\
\text { each part }\end{array}$ & $\begin{array}{l}\text { Anthers exposed } \\
\text { total number of } \\
\text { small flowers }\end{array}$ & $\begin{array}{l}\text { Total number } \\
\text { of small } \\
\text { flowers }\end{array}$ & $\begin{array}{l}\text { Single anther } \\
\text { exposure rate } \\
(\%)\end{array}$ & $\begin{array}{l}\text { Anther } \\
\text { exposure } \\
\text { rate (\%) }\end{array}$ \\
\hline \multirow{9}{*}{ Datong 27} & \multirow{3}{*}{$\begin{array}{c}\text { First } \\
\text { strain }\end{array}$} & Above & 54 & 71 & \multirow{3}{*}{162} & \multirow{3}{*}{213} & \multirow{3}{*}{76.06} & \multirow{9}{*}{76.96} \\
\hline & & Middle & 57 & 76 & & & & \\
\hline & & Below & 51 & 66 & & & & \\
\hline & \multirow{3}{*}{$\begin{array}{l}\text { Second } \\
\text { strain }\end{array}$} & Above & 51 & 61 & \multirow{3}{*}{165} & \multirow{3}{*}{207} & \multirow{3}{*}{79.71} & \\
\hline & & Middle & 60 & 76 & & & & \\
\hline & & Below & 54 & 70 & & & & \\
\hline & \multirow{3}{*}{$\begin{array}{l}\text { Third } \\
\text { strain }\end{array}$} & Above & 41 & 57 & \multirow{3}{*}{151} & \multirow{3}{*}{201} & \multirow{3}{*}{75.12} & \\
\hline & & Middle & 61 & 75 & & & & \\
\hline & & Below & 49 & 69 & & & & \\
\hline \multirow{9}{*}{ Datong 29} & \multirow{3}{*}{$\begin{array}{l}\text { First } \\
\text { strain }\end{array}$} & Above & 48 & 60 & \multirow{3}{*}{162} & \multirow{3}{*}{204} & \multirow{3}{*}{79.41} & \multirow{9}{*}{78.26} \\
\hline & & Middle & 64 & 79 & & & & \\
\hline & & Below & 50 & 65 & & & & \\
\hline & \multirow{3}{*}{$\begin{array}{l}\text { Second } \\
\text { strain }\end{array}$} & Above & 46 & 68 & \multirow{3}{*}{163} & \multirow{3}{*}{209} & \multirow{3}{*}{77.99} & \\
\hline & & Middle & 67 & 72 & & & & \\
\hline & & Below & 50 & 69 & & & & \\
\hline & \multirow{3}{*}{$\begin{array}{l}\text { Third } \\
\text { strain }\end{array}$} & Above & 45 & 67 & \multirow{3}{*}{154} & \multirow{3}{*}{199} & \multirow{3}{*}{77.39} & \\
\hline & & Middle & 57 & 71 & & & & \\
\hline & & Below & 52 & 61 & & & & \\
\hline
\end{tabular}


Q. Li et al.

Table S3-1. The statistical results of stigma exposure rate of DZ759A, KM58A and KM249A in 2013.

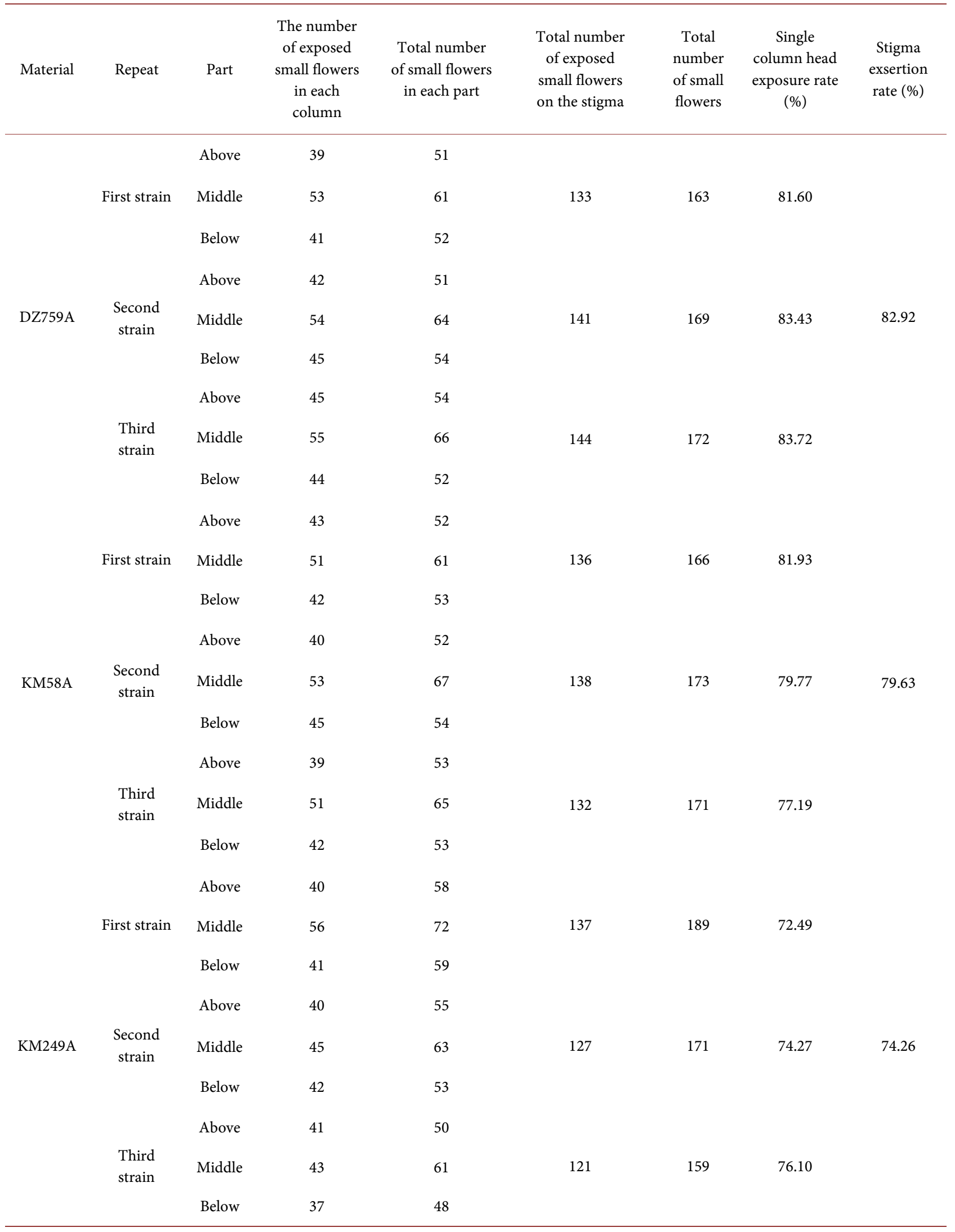


Table S3-2. The statistical results of stigma exposure rate of DZ759A, KM58A and KM249A in 2014.

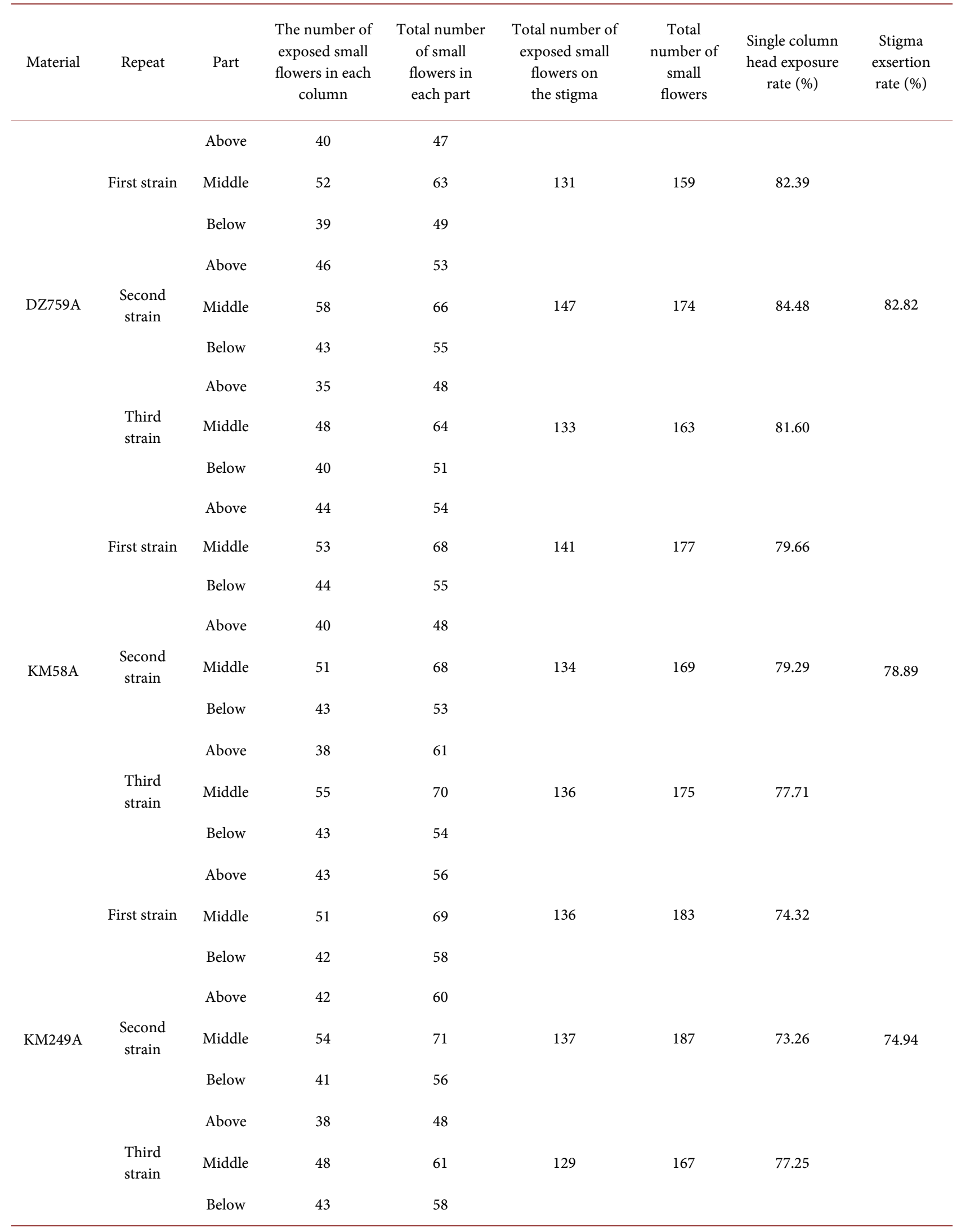


Q. Li et al.

Table S4-1. The statistical results of anther exposure rate of HK902 and HK950 in 2013.

\begin{tabular}{|c|c|c|c|c|c|c|c|c|}
\hline Material & Repeat & Part & $\begin{array}{c}\text { Number of exposed small } \\
\text { flowers in various parts } \\
\text { of the valley }\end{array}$ & $\begin{array}{l}\text { Total number of } \\
\text { small flowers in } \\
\text { each part }\end{array}$ & $\begin{array}{c}\text { Anthers exposed } \\
\text { total number of } \\
\text { small flowers }\end{array}$ & $\begin{array}{l}\text { Total number } \\
\text { of small } \\
\text { flowers }\end{array}$ & $\begin{array}{l}\text { Single anther } \\
\text { exposure rate } \\
(\%)\end{array}$ & $\begin{array}{l}\text { Anther } \\
\text { exposure } \\
\text { rate (\%) }\end{array}$ \\
\hline \multirow{9}{*}{ HK902 } & \multirow{3}{*}{$\begin{array}{c}\text { First } \\
\text { strain }\end{array}$} & Above & 46 & 60 & \multirow{3}{*}{147} & \multirow{3}{*}{190} & \multirow{3}{*}{77.37} & \multirow{9}{*}{77.13} \\
\hline & & Middle & 51 & 68 & & & & \\
\hline & & Below & 50 & 62 & & & & \\
\hline & \multirow{3}{*}{$\begin{array}{l}\text { Second } \\
\text { strain }\end{array}$} & Above & 49 & 62 & \multirow{3}{*}{153} & \multirow{3}{*}{192} & \multirow{3}{*}{79.69} & \\
\hline & & Middle & 56 & 69 & & & & \\
\hline & & Below & 48 & 61 & & & & \\
\hline & \multirow{3}{*}{$\begin{array}{l}\text { Third } \\
\text { strain }\end{array}$} & Above & 47 & 62 & \multirow{3}{*}{139} & \multirow{3}{*}{187} & \multirow{3}{*}{74.33} & \\
\hline & & Middle & 49 & 66 & & & & \\
\hline & & Below & 43 & 59 & & & & \\
\hline \multirow{9}{*}{ НК950 } & \multirow{3}{*}{$\begin{array}{l}\text { First } \\
\text { strain }\end{array}$} & Above & 49 & 61 & \multirow{3}{*}{146} & \multirow{3}{*}{187} & \multirow{3}{*}{78.07} & \multirow{9}{*}{78.13} \\
\hline & & Middle & 55 & 65 & & & & \\
\hline & & Below & 42 & 61 & & & & \\
\hline & \multirow{3}{*}{$\begin{array}{l}\text { Second } \\
\text { strain }\end{array}$} & Above & 50 & 63 & \multirow{3}{*}{149} & \multirow{3}{*}{189} & \multirow{3}{*}{78.84} & \\
\hline & & Middle & 54 & 66 & & & & \\
\hline & & Below & 45 & 60 & & & & \\
\hline & \multirow{3}{*}{$\begin{array}{l}\text { Third } \\
\text { strain }\end{array}$} & Above & 46 & 61 & \multirow{3}{*}{141} & \multirow{3}{*}{182} & \multirow{3}{*}{77.47} & \\
\hline & & Middle & 53 & 63 & & & & \\
\hline & & Below & 42 & 58 & & & & \\
\hline
\end{tabular}

Table S4-2. The statistical results of anther exposure rate of HK902 and HK950 in 2014.

\begin{tabular}{|c|c|c|c|c|c|c|c|c|}
\hline Material & Repeat & Part & $\begin{array}{l}\text { Number of exposed } \\
\text { small flowers in various } \\
\text { parts of the valley }\end{array}$ & $\begin{array}{l}\text { Total number of } \\
\text { small flowers in } \\
\text { each part }\end{array}$ & $\begin{array}{l}\text { Anthers exposed } \\
\text { total number of } \\
\text { small flowers }\end{array}$ & $\begin{array}{l}\text { Total number } \\
\text { of small } \\
\text { flowers }\end{array}$ & $\begin{array}{c}\text { Single anther } \\
\text { exposure rate } \\
(\%)\end{array}$ & $\begin{array}{l}\text { Anther } \\
\text { exposure } \\
\text { rate }(\%)\end{array}$ \\
\hline \multirow{9}{*}{ HK902 } & \multirow{3}{*}{$\begin{array}{c}\text { First } \\
\text { strain }\end{array}$} & Above & 48 & 67 & \multirow{3}{*}{164} & \multirow{3}{*}{209} & \multirow{3}{*}{78.47} & \multirow{9}{*}{77.19} \\
\hline & & Middle & 63 & 77 & & & & \\
\hline & & Below & 53 & 65 & & & & \\
\hline & \multirow{3}{*}{$\begin{array}{l}\text { Second } \\
\text { strain }\end{array}$} & Above & 48 & 59 & \multirow{3}{*}{152} & \multirow{3}{*}{198} & \multirow{3}{*}{76.77} & \\
\hline & & Middle & 57 & 77 & & & & \\
\hline & & Below & 47 & 62 & & & & \\
\hline & \multirow{3}{*}{$\begin{array}{l}\text { Third } \\
\text { strain }\end{array}$} & Above & 45 & 62 & \multirow{3}{*}{158} & \multirow{3}{*}{207} & \multirow{3}{*}{76.33} & \\
\hline & & Middle & 54 & 76 & & & & \\
\hline & & Below & 49 & 69 & & & & \\
\hline \multirow{9}{*}{ HK950 } & \multirow{3}{*}{$\begin{array}{l}\text { First } \\
\text { strain }\end{array}$} & Above & 43 & 58 & \multirow{3}{*}{159} & \multirow{3}{*}{203} & \multirow{3}{*}{78.33} & \multirow{9}{*}{77.86} \\
\hline & & Middle & 69 & 81 & & & & \\
\hline & & Below & 47 & 64 & & & & \\
\hline & \multirow{3}{*}{$\begin{array}{l}\text { Second } \\
\text { strain }\end{array}$} & Above & 41 & 57 & \multirow{3}{*}{148} & \multirow{3}{*}{192} & \multirow{3}{*}{77.08} & \\
\hline & & Middle & 63 & 74 & & & & \\
\hline & & Below & 44 & 61 & & & & \\
\hline & \multirow{3}{*}{$\begin{array}{l}\text { Third } \\
\text { strain }\end{array}$} & Above & 44 & 57 & \multirow{3}{*}{154} & \multirow{3}{*}{197} & \multirow{3}{*}{78.17} & \\
\hline & & Middle & 63 & 77 & & & & \\
\hline & & Below & 47 & 63 & & & & \\
\hline
\end{tabular}


Table S5. The schedule of leaf development dynamics of the sterile lines (DZ759A, KM58A and KM249A) and restorer lines (HK902 and HK950) in the foxtail millet research experimental station of Luanan of Tangshan normal university during 2016.

\begin{tabular}{|c|c|c|c|c|c|c|c|c|c|c|c|c|c|c|c|c|c|c|c|c|c|c|}
\hline Variety & $\begin{array}{c}\text { Sowing } \\
\text { date }\end{array}$ & $\begin{array}{cc}1 & 2 \\
\text { leaf } & \text { leaf }\end{array}$ & $\begin{array}{c}3 \\
\text { leaf }\end{array}$ & $\begin{array}{c}4 \\
\text { leaf }\end{array}$ & $\begin{array}{c}5 \\
\text { leaf }\end{array}$ & $\begin{array}{c}6 \\
\text { leaf }\end{array}$ & $\begin{array}{c}7 \\
\text { leaf }\end{array}$ & $\begin{array}{c}8 \\
\text { leaf }\end{array}$ & $\begin{array}{c}9 \\
\text { leaf }\end{array}$ & $\begin{array}{c}10 \\
\text { leaf }\end{array}$ & $\begin{array}{c}11 \\
\text { leaf }\end{array}$ & $\begin{array}{c}12 \\
\text { leaf }\end{array}$ & $\begin{array}{c}13 \\
\text { leaf }\end{array}$ & $\begin{array}{c}14 \\
\text { leaf }\end{array}$ & $\begin{array}{c}15 \\
\text { leaf }\end{array}$ & $\begin{array}{c}16 \\
\text { leaf }\end{array}$ & $\begin{array}{c}17 \\
\text { leaf }\end{array}$ & $\begin{array}{c}18 \\
\text { leaf }\end{array}$ & $\begin{array}{c}19 \\
\text { leaf }\end{array}$ & $\begin{array}{c}20 \\
\text { leaf }\end{array}$ & $\begin{array}{c}21 \\
\text { leaf }\end{array}$ & $\begin{array}{c}22 \\
\text { leaf }\end{array}$ \\
\hline HK950 & $6 / 7$ & $6 / 116 / 14$ & $6 / 17$ & $6 / 20$ & $6 / 23$ & $6 / 25$ & $6 / 28$ & $6 / 30$ & $7 / 3$ & $7 / 6$ & $7 / 8$ & $7 / 11$ & $7 / 13$ & $7 / 15$ & $7 / 18$ & $7 / 20$ & $7 / 22$ & $7 / 25$ & $7 / 28$ & $7 / 30$ & $8 / 2$ & $8 / 5$ \\
\hline HК902 & $6 / 7$ & $6 / 116 / 14$ & $6 / 17$ & $6 / 19$ & $6 / 22$ & $6 / 24$ & $6 / 27$ & $6 / 30$ & $7 / 3$ & $7 / 6$ & $7 / 8$ & $7 / 11$ & $7 / 13$ & $7 / 15$ & $7 / 18$ & $7 / 20$ & $7 / 22$ & $7 / 25$ & $7 / 28$ & $7 / 30$ & $8 / 2$ & $8 / 4$ \\
\hline DZ759A1 & $6 / 7$ & $6 / 116 / 14$ & $6 / 17$ & $6 / 20$ & $6 / 23$ & $6 / 25$ & $6 / 28$ & $6 / 30$ & $7 / 3$ & $7 / 6$ & $7 / 8$ & $7 / 11$ & $7 / 13$ & $7 / 15$ & $7 / 18$ & $7 / 20$ & $7 / 22$ & $7 / 25$ & $7 / 28$ & $7 / 30$ & $8 / 1$ & \\
\hline DZ759A2 & $6 / 8$ & $6 / 126 / 15$ & $6 / 18$ & $6 / 21$ & $6 / 24$ & $6 / 26$ & $6 / 29$ & $7 / 1$ & $7 / 4$ & $7 / 7$ & $7 / 9$ & $7 / 12$ & $7 / 14$ & $7 / 16$ & $7 / 19$ & $7 / 21$ & $7 / 23$ & $7 / 26$ & $7 / 29$ & $7 / 31$ & $8 / 2$ & \\
\hline DZ759A3 & $6 / 9$ & $6 / 136 / 16$ & $6 / 19$ & $6 / 22$ & $6 / 25$ & $6 / 27$ & $6 / 30$ & $7 / 2$ & $7 / 5$ & $7 / 8$ & $7 / 10$ & $7 / 13$ & $7 / 15$ & $7 / 17$ & $7 / 20$ & $7 / 22$ & $7 / 24$ & $7 / 27$ & $7 / 30$ & $8 / 1$ & $8 / 3$ & \\
\hline DZ759A4 & $6 / 10$ & $6 / 146 / 17$ & $6 / 20$ & $6 / 23$ & $6 / 26$ & $6 / 28$ & $7 / 1$ & $7 / 3$ & $7 / 6$ & $7 / 9$ & $7 / 11$ & $7 / 14$ & $7 / 16$ & $7 / 18$ & $7 / 21$ & $7 / 23$ & $7 / 25$ & $7 / 28$ & $7 / 31$ & $8 / 2$ & $8 / 4$ & \\
\hline DZ759A5 & $6 / 11$ & $6 / 156 / 18$ & $6 / 21$ & $6 / 24$ & $6 / 27$ & $6 / 29$ & $7 / 2$ & $7 / 4$ & $7 / 7$ & $7 / 10$ & $7 / 12$ & $7 / 15$ & $7 / 17$ & $7 / 19$ & $7 / 22$ & $7 / 24$ & $7 / 26$ & $7 / 29$ & $8 / 1$ & $8 / 3$ & $8 / 5$ & \\
\hline DZ759A6 & $6 / 12$ & $6 / 166 / 19$ & $6 / 22$ & $6 / 25$ & $6 / 28$ & $6 / 30$ & $7 / 3$ & $7 / 5$ & $7 / 8$ & $7 / 11$ & $7 / 13$ & $7 / 16$ & $7 / 18$ & $7 / 20$ & $7 / 23$ & $7 / 25$ & $7 / 27$ & $7 / 30$ & $8 / 2$ & $8 / 4$ & $8 / 6$ & \\
\hline DZ759A7 & $6 / 13$ & $6 / 176 / 21$ & $6 / 23$ & $6 / 26$ & $6 / 29$ & $7 / 1$ & $7 / 4$ & $7 / 6$ & $7 / 9$ & $7 / 12$ & $7 / 14$ & $7 / 17$ & $7 / 19$ & $7 / 21$ & $7 / 24$ & $7 / 26$ & $7 / 28$ & $7 / 31$ & $8 / 3$ & $8 / 5$ & $8 / 7$ & \\
\hline DZ759A8 & $6 / 14$ & $6 / 186 / 21$ & $6 / 24$ & $6 / 27$ & $6 / 30$ & $7 / 2$ & $7 / 5$ & $7 / 7$ & $7 / 10$ & $7 / 13$ & $7 / 15$ & $7 / 18$ & $7 / 20$ & $7 / 22$ & $7 / 25$ & $7 / 27$ & $7 / 29$ & $8 / 1$ & $8 / 4$ & $8 / 6$ & $8 / 8$ & \\
\hline DZ759A9 & $6 / 15$ & $6 / 196 / 22$ & $6 / 25$ & $6 / 27$ & $7 / 1$ & $7 / 3$ & $7 / 6$ & $7 / 8$ & $7 / 11$ & $7 / 14$ & $7 / 16$ & $7 / 19$ & $7 / 21$ & $7 / 23$ & $7 / 26$ & $7 / 28$ & $7 / 30$ & $8 / 2$ & $8 / 5$ & $8 / 7$ & $8 / 9$ & \\
\hline DZ759A10 & $6 / 16$ & $6 / 206 / 23$ & $6 / 26$ & $6 / 29$ & $7 / 2$ & $7 / 5$ & $7 / 7$ & $7 / 9$ & $7 / 12$ & $7 / 15$ & $7 / 17$ & $7 / 20$ & $7 / 22$ & $7 / 24$ & $7 / 27$ & $7 / 29$ & $7 / 31$ & $8 / 3$ & $8 / 6$ & $8 / 8$ & $8 / 10$ & \\
\hline DZ759A11 & $6 / 17$ & $6 / 216 / 24$ & $6 / 27$ & $6 / 30$ & $7 / 3$ & $7 / 5$ & $7 / 8$ & $7 / 11$ & $7 / 13$ & $7 / 16$ & $7 / 18$ & $7 / 21$ & $7 / 23$ & $7 / 25$ & $7 / 28$ & $7 / 30$ & $8 / 1$ & $8 / 4$ & $8 / 7$ & $8 / 9$ & $8 / 11$ & \\
\hline DZ759A12 & $6 / 18$ & $6 / 226 / 25$ & $6 / 28$ & $7 / 1$ & $7 / 4$ & $7 / 6$ & $7 / 9$ & $7 / 11$ & $7 / 14$ & $7 / 17$ & $7 / 19$ & $7 / 22$ & $7 / 24$ & $7 / 26$ & $7 / 29$ & $7 / 31$ & $8 / 2$ & $8 / 5$ & $8 / 8$ & $8 / 10$ & $8 / 12$ & \\
\hline DZ759A13 & $6 / 19$ & $6 / 236 / 26$ & $6 / 29$ & $7 / 2$ & $7 / 5$ & $7 / 7$ & $7 / 10$ & $7 / 12$ & $7 / 15$ & $7 / 18$ & $7 / 20$ & $7 / 23$ & $7 / 25$ & $7 / 27$ & $7 / 30$ & $8 / 1$ & $8 / 3$ & $8 / 6$ & $8 / 9$ & $8 / 11$ & $8 / 13$ & \\
\hline DZ759A14 & $6 / 20$ & $6 / 246 / 27$ & $6 / 30$ & $7 / 3$ & $7 / 6$ & $7 / 8$ & $7 / 11$ & $7 / 13$ & $7 / 16$ & $7 / 19$ & $7 / 21$ & $7 / 24$ & $7 / 26$ & $7 / 28$ & $7 / 31$ & $8 / 2$ & $8 / 4$ & $8 / 7$ & $8 / 10$ & $8 / 12$ & $8 / 14$ & \\
\hline DZ759A15 & $6 / 21$ & $6 / 256 / 29$ & $7 / 1$ & $7 / 4$ & $7 / 7$ & $7 / 9$ & $7 / 12$ & $7 / 14$ & $7 / 17$ & $7 / 20$ & $7 / 22$ & $7 / 25$ & $7 / 27$ & $7 / 29$ & $8 / 1$ & $8 / 3$ & $8 / 5$ & $8 / 8$ & $8 / 11$ & $8 / 13$ & $8 / 15$ & \\
\hline DZ759A16 & $6 / 22$ & $6 / 266 / 30$ & $7 / 2$ & $7 / 5$ & $7 / 8$ & $7 / 10$ & $7 / 13$ & $7 / 16$ & $7 / 18$ & $7 / 21$ & $7 / 23$ & $7 / 26$ & $7 / 28$ & $7 / 30$ & $8 / 2$ & $8 / 4$ & $8 / 6$ & $8 / 9$ & $8 / 12$ & $8 / 14$ & $8 / 16$ & \\
\hline DZ759A17 & $6 / 23$ & $6 / 276 / 30$ & $7 / 3$ & $7 / 6$ & $7 / 9$ & $7 / 11$ & $7 / 14$ & $7 / 16$ & $7 / 19$ & $7 / 22$ & $7 / 24$ & $7 / 27$ & $7 / 29$ & $7 / 31$ & $8 / 3$ & $8 / 5$ & $8 / 7$ & $8 / 10$ & $8 / 13$ & $8 / 15$ & $8 / 17$ & \\
\hline DZ759A18 & $6 / 24$ & $6 / 28 \quad 7 / 1$ & $7 / 4$ & $7 / 7$ & $7 / 10$ & $7 / 12$ & $7 / 15$ & $7 / 17$ & $7 / 20$ & $7 / 23$ & $7 / 25$ & $7 / 28$ & $7 / 30$ & $8 / 1$ & $8 / 4$ & $8 / 6$ & $8 / 8$ & $8 / 11$ & $8 / 14$ & $8 / 16$ & $8 / 18$ & \\
\hline DZ759A19 & $6 / 25$ & $6 / 29 \quad 7 / 2$ & $7 / 5$ & $7 / 8$ & $7 / 11$ & $7 / 13$ & $7 / 16$ & $7 / 18$ & $7 / 21$ & $7 / 24$ & $7 / 26$ & $7 / 29$ & $7 / 31$ & $8 / 2$ & $8 / 5$ & $8 / 7$ & $8 / 9$ & $8 / 12$ & $8 / 15$ & $8 / 17$ & $8 / 19$ & \\
\hline DZ759A20 & $6 / 26$ & $6 / 30 \quad 7 / 3$ & $7 / 6$ & $7 / 9$ & $7 / 12$ & $7 / 14$ & $7 / 17$ & $7 / 19$ & $7 / 22$ & $7 / 25$ & $7 / 27$ & $7 / 30$ & $8 / 1$ & $8 / 3$ & $8 / 6$ & $8 / 8$ & $8 / 10$ & $8 / 13$ & $8 / 16$ & $8 / 18$ & $8 / 20$ & \\
\hline KM58A1 & $6 / 7$ & $6 / 116 / 14$ & $6 / 17$ & $6 / 20$ & $6 / 23$ & $6 / 25$ & $6 / 28$ & $6 / 30$ & $7 / 3$ & $7 / 6$ & $7 / 8$ & $7 / 11$ & $7 / 13$ & $7 / 15$ & $7 / 18$ & $7 / 20$ & $7 / 22$ & $7 / 25$ & & & & \\
\hline KM58A2 & $6 / 8$ & $6 / 126 / 15$ & $6 / 18$ & $6 / 21$ & $6 / 24$ & $6 / 26$ & $6 / 29$ & $7 / 1$ & $7 / 4$ & $7 / 7$ & $7 / 9$ & $7 / 12$ & $7 / 14$ & $7 / 16$ & $7 / 19$ & $7 / 21$ & $7 / 23$ & $7 / 26$ & & & & \\
\hline KM58A3 & $6 / 9$ & $6 / 136 / 16$ & $6 / 19$ & $6 / 22$ & $6 / 25$ & $6 / 27$ & $6 / 30$ & $7 / 2$ & $7 / 5$ & $7 / 8$ & $7 / 10$ & $7 / 13$ & $7 / 15$ & $7 / 17$ & $7 / 20$ & $7 / 22$ & $7 / 24$ & $7 / 27$ & & & & \\
\hline KM58A4 & $6 / 10$ & $6 / 146 / 17$ & $6 / 20$ & $6 / 23$ & $6 / 26$ & $6 / 28$ & $7 / 1$ & $7 / 3$ & $7 / 6$ & $7 / 9$ & $7 / 11$ & $7 / 14$ & $7 / 16$ & $7 / 18$ & $7 / 21$ & $7 / 23$ & $7 / 25$ & $7 / 28$ & & & & \\
\hline KM58A5 & $6 / 11$ & $6 / 156 / 18$ & $6 / 21$ & $6 / 24$ & $6 / 27$ & $6 / 29$ & $7 / 2$ & $7 / 4$ & $7 / 7$ & $7 / 10$ & $7 / 12$ & $7 / 15$ & $7 / 17$ & $7 / 19$ & $7 / 22$ & $7 / 24$ & $7 / 26$ & $7 / 29$ & & & & \\
\hline KM58A6 & $6 / 12$ & $6 / 166 / 19$ & $6 / 22$ & $6 / 25$ & $6 / 28$ & $6 / 30$ & $7 / 3$ & $7 / 5$ & $7 / 8$ & $7 / 11$ & $7 / 13$ & $7 / 16$ & $7 / 18$ & $7 / 20$ & $7 / 23$ & $7 / 25$ & $7 / 27$ & $7 / 30$ & & & & \\
\hline KM58A7 & $6 / 13$ & $6 / 176 / 20$ & $6 / 23$ & $6 / 26$ & $6 / 29$ & $7 / 1$ & $7 / 4$ & $7 / 6$ & $7 / 9$ & $7 / 12$ & $7 / 14$ & $7 / 17$ & $7 / 19$ & $7 / 21$ & $7 / 24$ & $7 / 26$ & $7 / 28$ & $7 / 31$ & & & & \\
\hline KM58A8 & $6 / 14$ & $6 / 186 / 21$ & $6 / 23$ & $6 / 27$ & $6 / 30$ & $7 / 2$ & $7 / 5$ & $7 / 7$ & $7 / 10$ & $7 / 13$ & $7 / 15$ & $7 / 18$ & $7 / 20$ & $7 / 22$ & $7 / 25$ & $7 / 27$ & $7 / 29$ & $8 / 1$ & & & & \\
\hline
\end{tabular}


Q. Li et al.

\section{Continued}

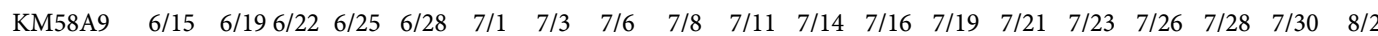

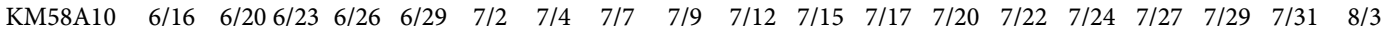

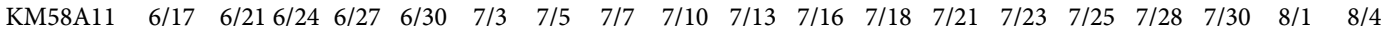

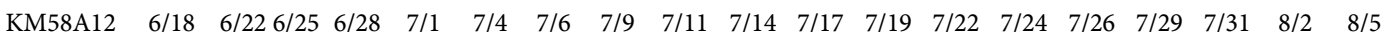

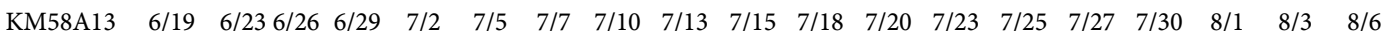

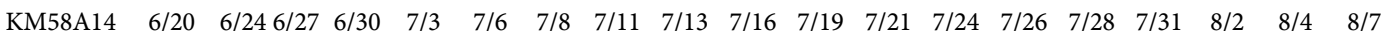

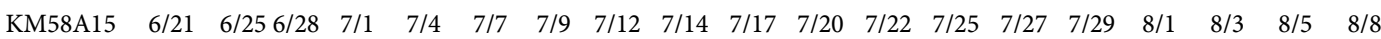

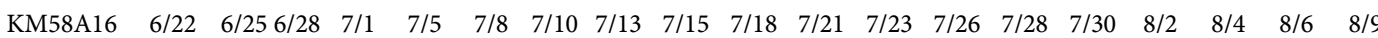

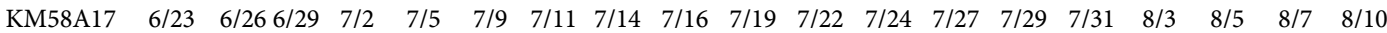

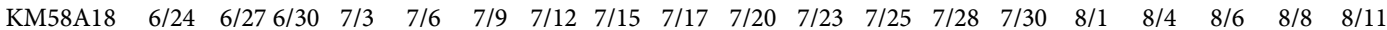

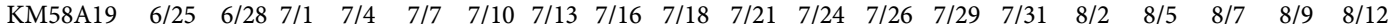

$\begin{array}{llllllllllllllllllll}\text { KM58A20 } & 6 / 26 & 6 / 29 & 7 / 2 & 7 / 5 & 7 / 8 & 7 / 11 & 7 / 14 & 7 / 17 & 7 / 19 & 7 / 22 & 7 / 25 & 7 / 27 & 7 / 30 & 8 / 1 & 8 / 3 & 8 / 6 & 8 / 8 & 8 / 10 & 8 / 13\end{array}$

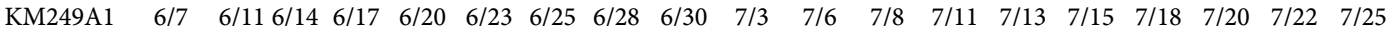

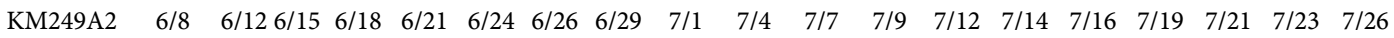

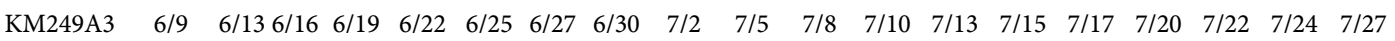

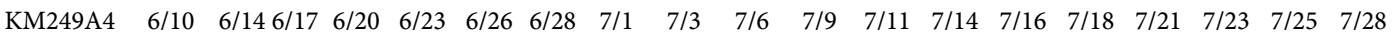

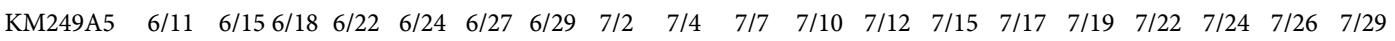

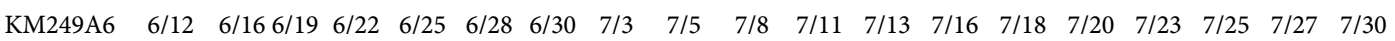

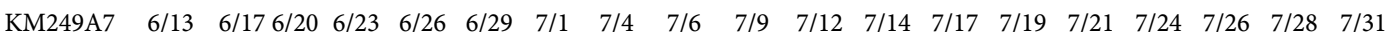

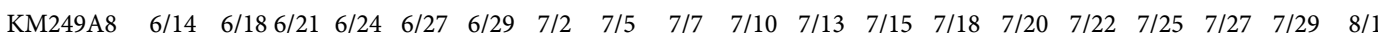

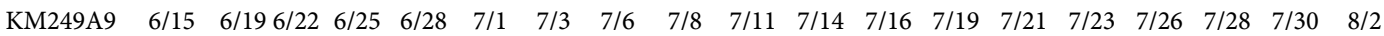

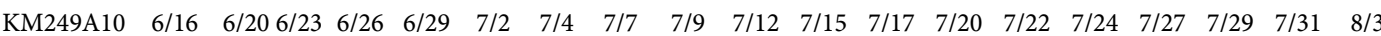

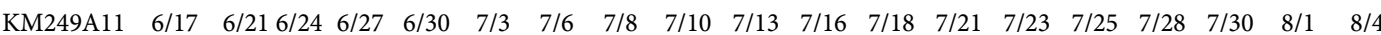

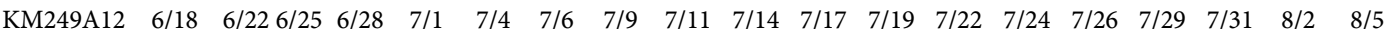

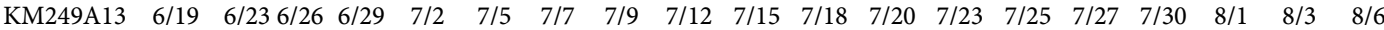

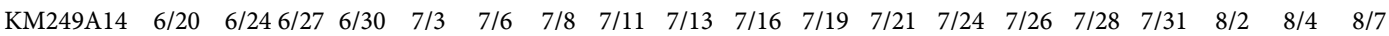

$\begin{array}{llllllllllllllllllll}\text { KM249A15 } & 6 / 21 & 6 / 25 & 6 / 29 & 7 / 1 & 7 / 4 & 7 / 7 & 7 / 9 & 7 / 12 & 7 / 14 & 7 / 17 & 7 / 20 & 7 / 22 & 7 / 25 & 7 / 27 & 7 / 29 & 8 / 1 & 8 / 3 & 8 / 5 & 8 / 8\end{array}$

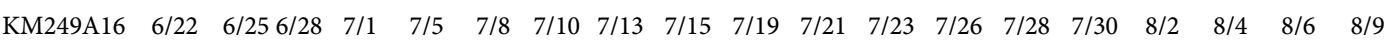

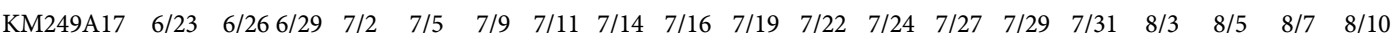

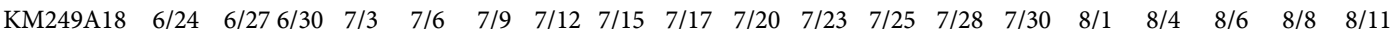

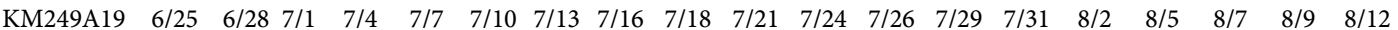

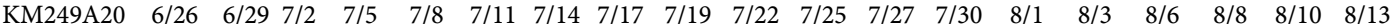


Table S6. The schedule of leaf development dynamics of the sterile lines (DZ759A, KM58A and KM249A) and restorer lines (HK902 and HK950) in the foxtail millet research experimental station of luanan of tangshan normal university during 2017.

\begin{tabular}{|c|c|c|c|c|c|c|c|c|c|c|c|c|c|c|c|c|c|c|c|c|c|c|c|}
\hline Variety & $\begin{array}{c}\text { Sowing } \\
\text { date }\end{array}$ & $\begin{array}{c}1 \\
\text { leaf }\end{array}$ & $\begin{array}{c}2 \\
\text { leaf }\end{array}$ & $\begin{array}{c}3 \\
\text { leaf }\end{array}$ & $\begin{array}{c}4 \\
\text { leaf }\end{array}$ & $\begin{array}{c}5 \\
\text { leaf }\end{array}$ & $\begin{array}{c}6 \\
\text { leaf }\end{array}$ & $\begin{array}{c}7 \\
\text { leaf }\end{array}$ & $\begin{array}{c}8 \\
\text { leaf }\end{array}$ & $\begin{array}{c}9 \\
\text { leaf }\end{array}$ & $\begin{array}{c}10 \\
\text { leaf }\end{array}$ & $\begin{array}{c}11 \\
\text { leaf }\end{array}$ & $\begin{array}{c}12 \\
\text { leaf }\end{array}$ & $\begin{array}{c}13 \\
\text { leaf }\end{array}$ & $\begin{array}{c}14 \\
\text { leaf }\end{array}$ & $\begin{array}{c}15 \\
\text { leaf }\end{array}$ & $\begin{array}{c}16 \\
\text { leaf }\end{array}$ & $\begin{array}{c}17 \\
\text { leaf }\end{array}$ & $\begin{array}{c}18 \\
\text { leaf }\end{array}$ & $\begin{array}{c}19 \\
\text { leaf }\end{array}$ & $\begin{array}{c}20 \\
\text { leaf }\end{array}$ & $\begin{array}{c}21 \\
\text { leaf }\end{array}$ & $\begin{array}{c}22 \\
\text { leaf }\end{array}$ \\
\hline HК950 & $6 / 13$ & $6 / 17$ & $6 / 20$ & $6 / 22$ & $6 / 24$ & $6 / 27$ & $6 / 29$ & $7 / 2$ & $7 / 4$ & $7 / 7$ & $7 / 10$ & $7 / 13$ & $7 / 15$ & $7 / 18$ & $7 / 20$ & $7 / 22$ & $7 / 25$ & $7 / 28$ & $7 / 30$ & $8 / 1$ & $8 / 4$ & $8 / 7$ & $8 / 9$ \\
\hline HK902 & $6 / 13$ & $6 / 17$ & $6 / 20$ & $6 / 22$ & $6 / 24$ & $6 / 27$ & $6 / 29$ & $7 / 1$ & $7 / 3$ & $7 / 5$ & $7 / 8$ & $7 / 11$ & $7 / 14$ & $7 / 17$ & $7 / 19$ & $7 / 21$ & $7 / 23$ & $7 / 26$ & $7 / 28$ & $7 / 30$ & $8 / 2$ & $8 / 5$ & $8 / 8$ \\
\hline DZ759A1 & $6 / 13$ & $6 / 17$ & $6 / 20$ & $6 / 23$ & $6 / 25$ & $6 / 27$ & $6 / 30$ & $7 / 2$ & $7 / 5$ & $7 / 8$ & $7 / 10$ & $7 / 12$ & $7 / 15$ & $7 / 18$ & $7 / 20$ & $7 / 22$ & $7 / 24$ & $7 / 27$ & $7 / 29$ & $8 / 1$ & $8 / 3$ & $8 / 5$ & \\
\hline DZ759A2 & $6 / 14$ & $6 / 18$ & $6 / 21$ & $6 / 24$ & $6 / 26$ & $6 / 29$ & $7 / 1$ & $7 / 4$ & $7 / 6$ & $7 / 8$ & $7 / 11$ & $7 / 13$ & $7 / 16$ & $7 / 19$ & $7 / 21$ & $7 / 23$ & $7 / 25$ & $7 / 28$ & $7 / 30$ & $8 / 2$ & $8 / 4$ & $8 / 6$ & \\
\hline DZ759A3 & $6 / 15$ & $6 / 19$ & $6 / 22$ & $6 / 25$ & $6 / 27$ & $6 / 29$ & $7 / 2$ & $7 / 5$ & $7 / 8$ & $7 / 10$ & $7 / 12$ & $7 / 14$ & $7 / 17$ & $7 / 20$ & $7 / 22$ & $7 / 24$ & $7 / 26$ & $7 / 28$ & $7 / 31$ & $8 / 3$ & $8 / 5$ & $8 / 7$ & \\
\hline DZ759A4 & $6 / 16$ & $6 / 20$ & $6 / 23$ & $6 / 26$ & $6 / 28$ & $6 / 30$ & $7 / 3$ & $7 / 6$ & $7 / 9$ & $7 / 12$ & $7 / 14$ & $7 / 16$ & $7 / 18$ & $7 / 21$ & $7 / 23$ & $7 / 25$ & $7 / 27$ & $7 / 29$ & $8 / 1$ & $8 / 3$ & $8 / 6$ & $8 / 8$ & \\
\hline DZ759A5 & $6 / 17$ & $6 / 21$ & $6 / 24$ & $6 / 27$ & $6 / 30$ & $7 / 2$ & $7 / 4$ & $7 / 7$ & $7 / 10$ & $7 / 12$ & $7 / 15$ & $7 / 17$ & $7 / 19$ & $7 / 21$ & $7 / 24$ & $7 / 26$ & $7 / 28$ & $7 / 30$ & $8 / 2$ & $8 / 4$ & $8 / 7$ & $8 / 9$ & \\
\hline DZ759A6 & $6 / 18$ & $6 / 22$ & $6 / 25$ & $6 / 28$ & $7 / 1$ & $7 / 3$ & $7 / 5$ & $7 / 7$ & $7 / 10$ & $7 / 13$ & $7 / 15$ & $7 / 18$ & $7 / 20$ & $7 / 22$ & $7 / 24$ & $7 / 27$ & $7 / 29$ & $8 / 1$ & $8 / 3$ & $8 / 5$ & $8 / 7$ & $8 / 10$ & \\
\hline DZ759A7 & $6 / 19$ & $6 / 23$ & $6 / 26$ & $6 / 29$ & $7 / 2$ & $7 / 5$ & $7 / 7$ & $7 / 9$ & $7 / 11$ & $7 / 14$ & $7 / 16$ & $7 / 19$ & $7 / 21$ & $7 / 23$ & $7 / 25$ & $7 / 27$ & $7 / 30$ & $8 / 2$ & $8 / 4$ & $8 / 6$ & $8 / 9$ & $8 / 11$ & \\
\hline DZ759A8 & $6 / 20$ & $6 / 24$ & $6 / 27$ & $6 / 30$ & $7 / 2$ & $7 / 5$ & $7 / 8$ & $7 / 10$ & $7 / 12$ & $7 / 14$ & $7 / 17$ & $7 / 20$ & $7 / 22$ & $7 / 24$ & $7 / 26$ & $7 / 28$ & $7 / 31$ & $8 / 3$ & $8 / 5$ & $8 / 7$ & $8 / 10$ & $8 / 12$ & \\
\hline DZ759A9 & $6 / 21$ & $6 / 25$ & $6 / 28$ & $6 / 30$ & $7 / 3$ & $7 / 6$ & $7 / 8$ & $7 / 11$ & $7 / 13$ & $7 / 15$ & $7 / 18$ & $7 / 21$ & $7 / 23$ & $7 / 25$ & $7 / 27$ & $7 / 29$ & $8 / 1$ & $8 / 4$ & $8 / 7$ & $8 / 9$ & $8 / 11$ & $8 / 13$ & \\
\hline DZ759A10 & $6 / 22$ & $6 / 26$ & $6 / 29$ & $7 / 1$ & $7 / 3$ & $7 / 6$ & $7 / 9$ & $7 / 12$ & $7 / 14$ & $7 / 16$ & $7 / 19$ & $7 / 22$ & $7 / 24$ & $7 / 26$ & $7 / 28$ & $7 / 30$ & $8 / 2$ & $8 / 5$ & $8 / 8$ & $8 / 10$ & $8 / 12$ & $8 / 14$ & \\
\hline DZ759A11 & $6 / 23$ & $6 / 27$ & $6 / 29$ & $7 / 1$ & $7 / 4$ & $7 / 7$ & $7 / 10$ & $7 / 13$ & $7 / 15$ & $7 / 17$ & $7 / 20$ & $7 / 23$ & $7 / 25$ & $7 / 28$ & $7 / 31$ & $8 / 3$ & $8 / 5$ & $8 / 8$ & $8 / 10$ & $8 / 12$ & $8 / 14$ & & \\
\hline DZ759A12 & $6 / 24$ & $6 / 28$ & $6 / 30$ & $7 / 2$ & $7 / 5$ & $7 / 8$ & $7 / 11$ & $7 / 14$ & $7 / 16$ & $7 / 18$ & $7 / 20$ & $7 / 23$ & $7 / 26$ & $7 / 29$ & $8 / 1$ & $8 / 4$ & $8 / 6$ & $8 / 9$ & $8 / 11$ & $8 / 13$ & $8 / 15$ & & \\
\hline DZ759A13 & $6 / 25$ & $6 / 28$ & $7 / 1$ & $7 / 3$ & $7 / 6$ & $7 / 9$ & $7 / 12$ & $7 / 15$ & $7 / 18$ & $7 / 20$ & $7 / 22$ & $7 / 24$ & $7 / 27$ & $7 / 30$ & $8 / 2$ & $8 / 5$ & $8 / 7$ & $8 / 10$ & $8 / 12$ & $8 / 14$ & $8 / 16$ & & \\
\hline DZ759A15 & $6 / 27$ & $6 / 30$ & $7 / 3$ & $7 / 5$ & $7 / 8$ & $7 / 11$ & $7 / 13$ & $7 / 16$ & $7 / 19$ & $7 / 22$ & $7 / 24$ & $7 / 26$ & $7 / 29$ & $8 / 1$ & $8 / 4$ & $8 / 7$ & $8 / 9$ & $8 / 11$ & $8 / 14$ & $8 / 16$ & $8 / 18$ & & \\
\hline DZ759A16 & $6 / 28$ & $7 / 1$ & $7 / 4$ & $7 / 6$ & $7 / 9$ & $7 / 11$ & $7 / 14$ & $7 / 17$ & $7 / 20$ & $7 / 22$ & $7 / 24$ & $7 / 27$ & $7 / 30$ & $8 / 2$ & $8 / 5$ & $8 / 8$ & $8 / 10$ & $8 / 12$ & $8 / 15$ & $8 / 17$ & $8 / 19$ & & \\
\hline DZ759A17 & $6 / 29$ & $7 / 2$ & $7 / 5$ & $7 / 8$ & $7 / 10$ & $7 / 12$ & $7 / 15$ & $7 / 18$ & $7 / 21$ & $7 / 23$ & $7 / 25$ & $7 / 28$ & $7 / 31$ & $8 / 3$ & $8 / 5$ & $8 / 8$ & $8 / 11$ & $8 / 13$ & $8 / 16$ & $8 / 18$ & $8 / 20$ & & \\
\hline DZ759A18 & $6 / 30$ & $7 / 3$ & $7 / 6$ & $7 / 9$ & $7 / 11$ & $7 / 14$ & $7 / 16$ & $7 / 18$ & $7 / 21$ & $7 / 23$ & $7 / 26$ & $7 / 29$ & $8 / 1$ & $8 / 4$ & $8 / 7$ & $8 / 9$ & $8 / 12$ & $8 / 14$ & $8 / 17$ & $8 / 19$ & $8 / 21$ & & \\
\hline DZ759A19 & $7 / 1$ & $7 / 4$ & $7 / 7$ & $7 / 9$ & $7 / 12$ & $7 / 15$ & $7 / 17$ & $7 / 19$ & $7 / 21$ & $7 / 24$ & $7 / 27$ & $7 / 30$ & $8 / 1$ & $8 / 4$ & $8 / 7$ & $8 / 10$ & $8 / 13$ & $8 / 16$ & $8 / 18$ & $8 / 20$ & $8 / 22$ & & \\
\hline DZ759A20 & $7 / 2$ & $7 / 5$ & $7 / 8$ & $7 / 10$ & $7 / 13$ & $7 / 16$ & $7 / 18$ & $7 / 20$ & $7 / 22$ & $7 / 25$ & $7 / 28$ & $7 / 31$ & $8 / 2$ & $8 / 5$ & $8 / 8$ & $8 / 11$ & $8 / 14$ & $8 / 17$ & $8 / 19$ & $8 / 21$ & $8 / 23$ & & \\
\hline KM58A1 & $6 / 13$ & $6 / 17$ & $6 / 20$ & $6 / 23$ & $6 / 25$ & $6 / 28$ & $6 / 30$ & $7 / 2$ & $7 / 5$ & $7 / 8$ & $7 / 10$ & $7 / 13$ & $7 / 15$ & $7 / 18$ & $7 / 20$ & $7 / 22$ & $7 / 24$ & $7 / 27$ & $7 / 29$ & & & & \\
\hline KM58A2 & $6 / 14$ & $6 / 18$ & $6 / 21$ & $6 / 24$ & $6 / 27$ & $6 / 29$ & $7 / 1$ & $7 / 4$ & $7 / 6$ & $7 / 8$ & $7 / 10$ & $7 / 13$ & $7 / 16$ & $7 / 19$ & $7 / 21$ & $7 / 23$ & $7 / 25$ & $7 / 28$ & $7 / 30$ & & & & \\
\hline KM58A3 & $6 / 15$ & $6 / 19$ & $6 / 22$ & $6 / 24$ & $6 / 27$ & $6 / 29$ & $7 / 2$ & $7 / 5$ & $7 / 8$ & $7 / 10$ & $7 / 12$ & $7 / 14$ & $7 / 17$ & $7 / 19$ & $7 / 22$ & $7 / 24$ & $7 / 26$ & $7 / 28$ & $7 / 31$ & & & & \\
\hline KM58A4 & $6 / 16$ & $6 / 20$ & $6 / 23$ & $6 / 25$ & $6 / 28$ & $6 / 30$ & $7 / 3$ & $7 / 6$ & $7 / 9$ & $7 / 11$ & $7 / 14$ & $7 / 16$ & $7 / 18$ & $7 / 21$ & $7 / 23$ & $7 / 25$ & $7 / 27$ & $7 / 29$ & $8 / 1$ & & & & \\
\hline KM58A5 & $6 / 17$ & $6 / 21$ & $6 / 24$ & $6 / 27$ & $6 / 30$ & $7 / 2$ & $7 / 5$ & $7 / 7$ & $7 / 10$ & $7 / 12$ & $7 / 15$ & $7 / 17$ & $7 / 19$ & $7 / 21$ & $7 / 24$ & $7 / 26$ & $7 / 28$ & $7 / 30$ & $8 / 2$ & & & & \\
\hline KM58A6 & $6 / 18$ & $6 / 22$ & $6 / 25$ & $6 / 28$ & $7 / 1$ & $7 / 3$ & $7 / 5$ & $7 / 7$ & $7 / 10$ & $7 / 13$ & $7 / 16$ & $7 / 18$ & $7 / 20$ & $7 / 22$ & $7 / 24$ & $7 / 27$ & $7 / 29$ & $8 / 1$ & $8 / 3$ & & & & \\
\hline KM58A7 & $6 / 19$ & $6 / 23$ & $6 / 26$ & $6 / 29$ & $7 / 2$ & $7 / 5$ & $7 / 7$ & $7 / 9$ & $7 / 11$ & $7 / 14$ & $7 / 17$ & $7 / 19$ & $7 / 21$ & $7 / 23$ & $7 / 25$ & $7 / 27$ & $7 / 30$ & $8 / 2$ & $8 / 4$ & & & & \\
\hline KM58A8 & $6 / 20$ & $6 / 24$ & $6 / 27$ & $6 / 30$ & $7 / 2$ & $7 / 5$ & $7 / 8$ & $7 / 10$ & $7 / 12$ & $7 / 15$ & $7 / 17$ & $7 / 20$ & $7 / 22$ & $7 / 24$ & $7 / 26$ & $7 / 28$ & $7 / 31$ & $8 / 3$ & $8 / 5$ & & & & \\
\hline
\end{tabular}


Q. Li et al.

\section{Continued}

\begin{tabular}{|c|c|c|c|c|c|c|c|c|c|c|c|c|c|c|c|c|c|c|c|}
\hline KM58A9 & $6 / 21$ & $6 / 25$ & $6 / 28$ & $6 / 30$ & $7 / 3$ & $7 / 6$ & $7 / 9$ & $7 / 11$ & $7 / 13$ & $7 / 15$ & $7 / 18$ & $7 / 21$ & $7 / 23$ & $7 / 25$ & $7 / 27$ & $7 / 29$ & $8 / 1$ & $8 / 4$ & $8 / 7$ \\
\hline KM58A10 & $6 / 22$ & $6 / 26$ & $6 / 29$ & $7 / 1$ & $7 / 3$ & $7 / 6$ & $7 / 9$ & $7 / 11$ & $7 / 14$ & $7 / 16$ & $7 / 19$ & $7 / 22$ & $7 / 24$ & $7 / 26$ & $7 / 28$ & $7 / 30$ & $8 / 2$ & $8 / 5$ & $8 / 8$ \\
\hline KM58A11 & $6 / 23$ & $6 / 27$ & $6 / 29$ & $7 / 1$ & $7 / 4$ & $7 / 7$ & $7 / 10$ & $7 / 12$ & $7 / 15$ & $7 / 17$ & $7 / 20$ & $7 / 23$ & $7 / 25$ & $7 / 28$ & $7 / 31$ & $8 / 3$ & $8 / 5$ & $8 / 8$ & \\
\hline KM58A12 & $6 / 24$ & $6 / 28$ & $6 / 30$ & $7 / 2$ & $7 / 5$ & $7 / 8$ & $7 / 11$ & $7 / 14$ & $7 / 16$ & $7 / 18$ & $7 / 20$ & $7 / 23$ & $7 / 26$ & $7 / 29$ & $8 / 1$ & $8 / 4$ & $8 / 6$ & $8 / 9$ & \\
\hline KM58A13 & $6 / 25$ & $6 / 28$ & $7 / 1$ & $7 / 3$ & $7 / 6$ & $7 / 9$ & $7 / 12$ & $7 / 15$ & $7 / 18$ & $7 / 20$ & $7 / 22$ & $7 / 24$ & $7 / 27$ & $7 / 30$ & $8 / 2$ & $8 / 5$ & $8 / 7$ & $8 / 10$ & \\
\hline KM58A14 & $6 / 26$ & $6 / 29$ & $7 / 2$ & $7 / 4$ & $7 / 7$ & $7 / 10$ & $7 / 13$ & $7 / 16$ & $7 / 19$ & $7 / 21$ & $7 / 23$ & $7 / 25$ & $7 / 28$ & $7 / 31$ & $8 / 3$ & $8 / 6$ & $8 / 8$ & $8 / 11$ & \\
\hline KM58A15 & $6 / 27$ & $6 / 30$ & $7 / 3$ & $7 / 6$ & $7 / 8$ & $7 / 10$ & $7 / 13$ & $7 / 16$ & $7 / 19$ & $7 / 22$ & $7 / 24$ & $7 / 26$ & $7 / 29$ & $8 / 1$ & $8 / 4$ & $8 / 7$ & $8 / 9$ & $8 / 11$ & \\
\hline KM58A16 & $6 / 28$ & $7 / 1$ & $7 / 4$ & $7 / 6$ & $7 / 9$ & $7 / 12$ & $7 / 14$ & $7 / 17$ & $7 / 20$ & $7 / 22$ & $7 / 24$ & $7 / 27$ & $7 / 30$ & $8 / 2$ & $8 / 5$ & $8 / 8$ & $8 / 10$ & $8 / 12$ & \\
\hline KM58A18 & $6 / 30$ & $7 / 3$ & $7 / 6$ & $7 / 9$ & $7 / 11$ & $7 / 14$ & $7 / 16$ & $7 / 18$ & $7 / 21$ & $7 / 24$ & $7 / 26$ & $7 / 29$ & $8 / 1$ & $8 / 4$ & $8 / 7$ & $8 / 9$ & $8 / 12$ & $8 / 14$ & \\
\hline KM58A19 & $7 / 1$ & $7 / 4$ & $7 / 7$ & $7 / 9$ & $7 / 12$ & $7 / 15$ & $7 / 17$ & $7 / 19$ & $7 / 21$ & $7 / 24$ & $7 / 27$ & $7 / 30$ & $8 / 1$ & $8 / 4$ & $8 / 7$ & $8 / 10$ & $8 / 13$ & $8 / 16$ & \\
\hline KM58A20 & $7 / 2$ & $7 / 5$ & $7 / 8$ & $7 / 10$ & $7 / 13$ & $7 / 16$ & $7 / 18$ & $7 / 20$ & $7 / 22$ & $7 / 25$ & $7 / 28$ & $7 / 31$ & $8 / 2$ & $8 / 5$ & $8 / 8$ & $8 / 11$ & $8 / 14$ & $8 / 17$ & \\
\hline KM249A1 & $6 / 13$ & $6 / 17$ & $6 / 20$ & $6 / 23$ & $6 / 25$ & $6 / 27$ & $6 / 30$ & $7 / 2$ & $7 / 5$ & $7 / 7$ & $7 / 9$ & $7 / 12$ & $7 / 15$ & $7 / 18$ & $7 / 20$ & $7 / 22$ & $7 / 24$ & $7 / 27$ & $7 / 29$ \\
\hline KM249A2 & $6 / 14$ & $6 / 18$ & $6 / 21$ & $6 / 24$ & $6 / 26$ & $6 / 29$ & $7 / 1$ & $7 / 4$ & $7 / 6$ & $7 / 8$ & $7 / 11$ & $7 / 13$ & $7 / 16$ & $7 / 19$ & $7 / 21$ & $7 / 23$ & $7 / 25$ & $7 / 28$ & $7 / 30$ \\
\hline KM249A3 & $6 / 15$ & $6 / 19$ & $6 / 22$ & $6 / 25$ & $6 / 27$ & $6 / 29$ & $7 / 2$ & $7 / 5$ & $7 / 8$ & $7 / 10$ & $7 / 12$ & $7 / 15$ & $7 / 17$ & $7 / 20$ & $7 / 22$ & $7 / 24$ & $7 / 26$ & $7 / 28$ & $7 / 31$ \\
\hline KM249A4 & $6 / 16$ & $6 / 20$ & $6 / 23$ & $6 / 26$ & $6 / 28$ & $6 / 30$ & $7 / 3$ & $7 / 6$ & $7 / 9$ & $7 / 12$ & $7 / 14$ & $7 / 16$ & $7 / 18$ & $7 / 20$ & $7 / 23$ & $7 / 25$ & $7 / 27$ & $7 / 29$ & $8 / 1$ \\
\hline KM249A6 & $6 / 18$ & $6 / 22$ & $6 / 25$ & $6 / 28$ & $7 / 1$ & $7 / 3$ & $7 / 5$ & $7 / 7$ & $7 / 10$ & $7 / 13$ & $7 / 15$ & $7 / 18$ & $7 / 20$ & $7 / 22$ & $7 / 24$ & $7 / 27$ & $7 / 29$ & $8 / 1$ & $8 / 3$ \\
\hline KM249A7 & $6 / 19$ & $6 / 23$ & $6 / 26$ & $6 / 29$ & $7 / 2$ & $7 / 5$ & $7 / 7$ & $7 / 9$ & $7 / 11$ & $7 / 14$ & $7 / 16$ & $7 / 19$ & $7 / 21$ & $7 / 23$ & $7 / 25$ & $7 / 27$ & $7 / 30$ & $8 / 2$ & $8 / 4$ \\
\hline KM249A8 & $6 / 20$ & $6 / 24$ & $6 / 27$ & $6 / 30$ & $7 / 2$ & $7 / 5$ & $7 / 8$ & $7 / 10$ & $7 / 12$ & $7 / 14$ & $7 / 17$ & $7 / 19$ & $7 / 22$ & $7 / 24$ & $7 / 26$ & $7 / 28$ & $7 / 31$ & $8 / 3$ & $8 / 5$ \\
\hline KM249A9 & $6 / 21$ & $6 / 25$ & $6 / 28$ & $6 / 30$ & $7 / 3$ & $7 / 6$ & $7 / 8$ & $7 / 11$ & $7 / 13$ & $7 / 15$ & $7 / 18$ & $7 / 20$ & $7 / 23$ & $7 / 25$ & $7 / 27$ & $7 / 29$ & $8 / 1$ & $8 / 4$ & $8 / 7$ \\
\hline KM249A10 & $6 / 22$ & $6 / 26$ & $6 / 29$ & $7 / 1$ & $7 / 3$ & $7 / 6$ & $7 / 9$ & $7 / 12$ & $7 / 14$ & $7 / 16$ & $7 / 19$ & $7 / 22$ & $7 / 24$ & $7 / 26$ & $7 / 28$ & $7 / 30$ & $8 / 2$ & $8 / 5$ & $8 / 8$ \\
\hline KM249A11 & $6 / 23$ & $6 / 27$ & $6 / 29$ & $7 / 1$ & $7 / 4$ & $7 / 7$ & $7 / 10$ & $7 / 13$ & $7 / 15$ & $7 / 17$ & $7 / 20$ & $7 / 23$ & $7 / 25$ & $7 / 28$ & $7 / 31$ & $8 / 3$ & $8 / 5$ & $8 / 7$ & $8 / 9$ \\
\hline KM249A12 & $6 / 24$ & $6 / 28$ & $6 / 30$ & $7 / 2$ & $7 / 5$ & $7 / 8$ & $7 / 11$ & $7 / 14$ & $7 / 16$ & $7 / 18$ & $7 / 20$ & $7 / 23$ & $7 / 26$ & $7 / 29$ & $8 / 1$ & $8 / 4$ & $8 / 6$ & $8 / 9$ & \\
\hline KM249A13 & $6 / 25$ & $6 / 28$ & $7 / 1$ & $7 / 4$ & $7 / 6$ & $7 / 9$ & $7 / 12$ & $7 / 15$ & $7 / 18$ & $7 / 20$ & $7 / 22$ & $7 / 24$ & $7 / 27$ & $7 / 30$ & $8 / 2$ & $8 / 5$ & $8 / 7$ & $8 / 10$ & \\
\hline KM249A14 & $6 / 26$ & $6 / 29$ & $7 / 2$ & $7 / 5$ & $7 / 7$ & $7 / 10$ & $7 / 13$ & $7 / 16$ & $7 / 18$ & $7 / 21$ & $7 / 23$ & $7 / 25$ & $7 / 28$ & $7 / 31$ & $8 / 3$ & $8 / 6$ & $8 / 8$ & $8 / 11$ & \\
\hline KM249A15 & $6 / 27$ & $6 / 30$ & $7 / 3$ & $7 / 6$ & $7 / 8$ & $7 / 11$ & $7 / 13$ & $7 / 16$ & $7 / 19$ & $7 / 22$ & $7 / 24$ & $7 / 26$ & $7 / 29$ & $8 / 1$ & $8 / 4$ & $8 / 7$ & $8 / 9$ & $8 / 11$ & \\
\hline KM249A16 & $6 / 28$ & $7 / 1$ & $7 / 4$ & $7 / 7$ & $7 / 9$ & $7 / 11$ & $7 / 14$ & $7 / 17$ & $7 / 20$ & $7 / 22$ & $7 / 24$ & $7 / 27$ & $7 / 30$ & $8 / 2$ & $8 / 5$ & $8 / 8$ & $8 / 10$ & $8 / 12$ & \\
\hline KM249A17 & $6 / 29$ & $7 / 2$ & $7 / 5$ & $7 / 7$ & $7 / 10$ & $7 / 12$ & $7 / 15$ & $7 / 18$ & $7 / 21$ & $7 / 23$ & $7 / 25$ & $7 / 28$ & $7 / 31$ & $8 / 3$ & $8 / 5$ & $8 / 8$ & $8 / 11$ & $8 / 13$ & \\
\hline KM249A18 & $6 / 30$ & $7 / 3$ & $7 / 6$ & $7 / 8$ & $7 / 11$ & $7 / 14$ & $7 / 16$ & $7 / 18$ & $7 / 21$ & $7 / 23$ & $7 / 26$ & $7 / 29$ & $8 / 1$ & $8 / 4$ & $8 / 7$ & $8 / 9$ & $8 / 12$ & $8 / 14$ & \\
\hline KM249A19 & $7 / 1$ & $7 / 4$ & $7 / 7$ & $7 / 10$ & $7 / 12$ & $7 / 15$ & $7 / 17$ & $7 / 19$ & $7 / 21$ & $7 / 24$ & $7 / 27$ & $7 / 30$ & $8 / 1$ & $8 / 4$ & $8 / 7$ & $8 / 10$ & $8 / 13$ & $8 / 16$ & \\
\hline KM249A20 & $7 / 2$ & $7 / 5$ & $7 / 8$ & $7 / 11$ & $7 / 14$ & $7 / 16$ & $7 / 18$ & $7 / 20$ & $7 / 22$ & $7 / 25$ & $7 / 28$ & $7 / 31$ & $8 / 2$ & $8 / 5$ & $8 / 8$ & $8 / 11$ & $8 / 14$ & $8 / 17$ & \\
\hline
\end{tabular}




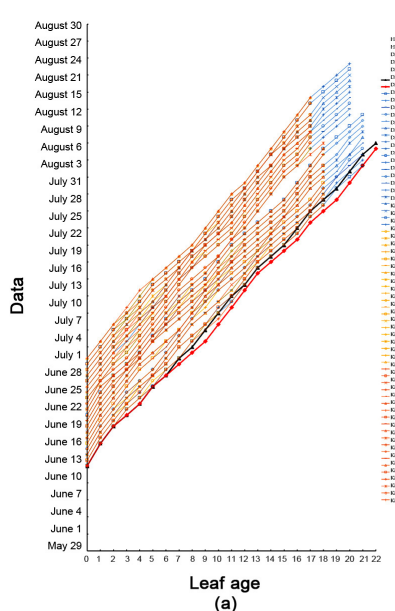

(a)

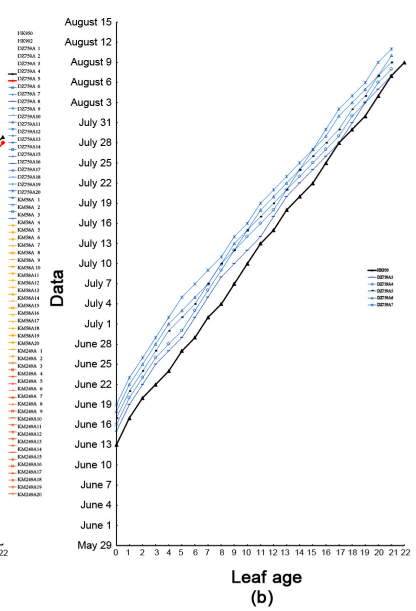

(b)

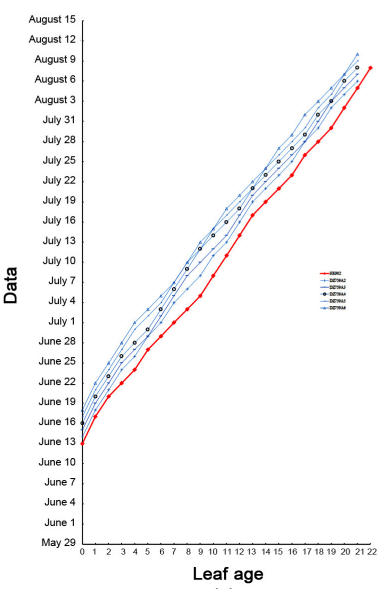

(e)
(eag
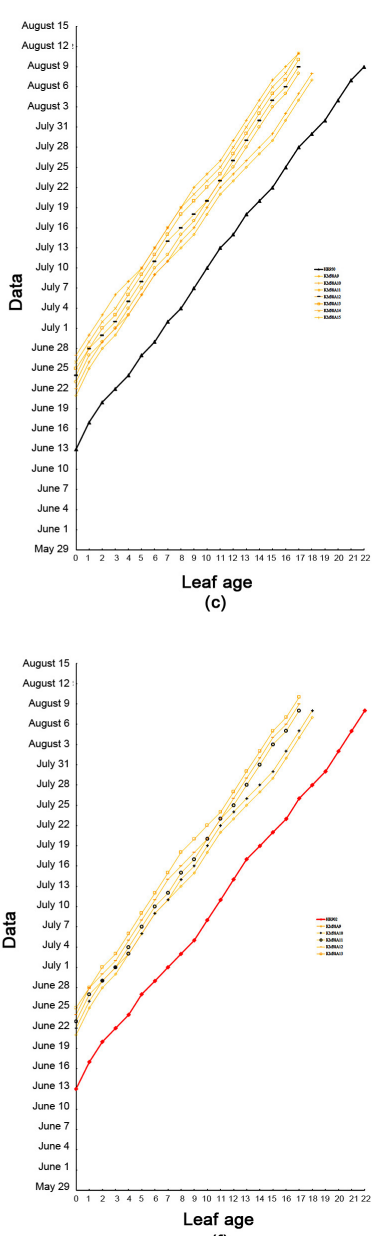

(f)
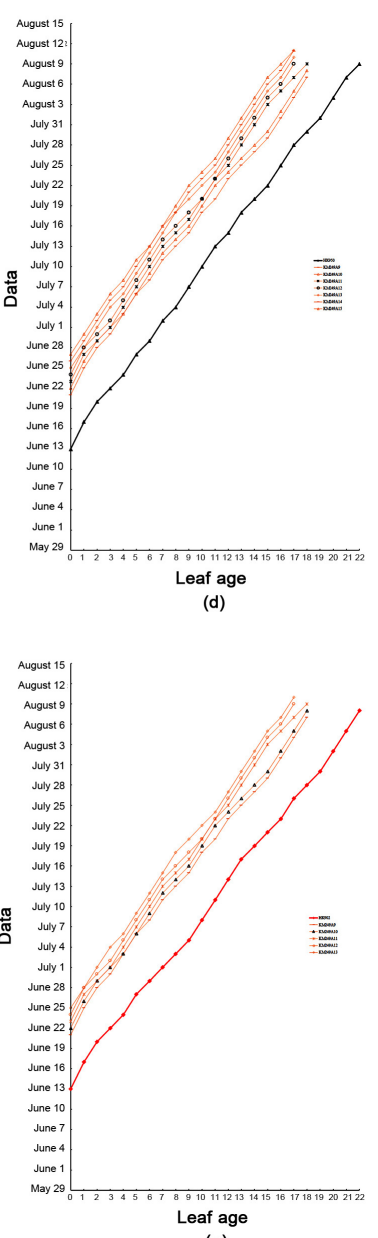

(g)

Figure S1. The developmental dynamics of leaf age and the corresponding maps of different control nodes of the sterile lines (DZ759A, KM58A and KM249A) and restorer lines (HK902 and HK950) during 2017 (The graph's horizontal axis shows the leaf age of the tested material, and the vertical axis shows the sowing date and the leaf development date). (a). Developmental dynamics of leaf age of the sterile lines (DZ759A, KM58A and KM249A) and restorer lines (HK902 and HK950) during 2017. (b). The control nodes of the restorer line (HK950) and sterile lines (DZ759A). (c). The control nodes of the restorer line (HK950) and sterile lines (KM58A). (d). The control nodes of the restorer line (HK950) and sterile lines (KM249A). (e). The control nodes of the restorer line (HK902) and sterile lines (DZ759A). (f). The control nodes of the restorer line (HK902) and sterile lines (KM58A). (g). The control nodes of the restorer line (HK902) and sterile lines (KM249A). 